\title{
I. DÜNYA SAVAŞI SIRASINDA OSMANLI VE HABSBURG HANEDANLARI ARASINDAKİ İLIŞKILER
}

\section{Şaban ORTAK ${ }^{*}$}

\author{
$\ddot{O} \mathbf{z}$
}

Yüzlerce yıllık biriken sorunların ve gidişatın sonucu kaçınılmaz hale gelen I. Dünya Savaşı, tarihin gördüğü ilk büyük savaş olarak tarihte yerini almıştır. Uzun yıllar Balkanlarda hâkimiyet mücadelesi veren ve bire bir veya bloklar halinde savaşan Osmanlı ve Avusturya-Macaristan İmparatorlukları bu savaş öncesinde Almanya öncülüğündeki İttifak Devletleri bloğunda yer alarak kader birliği yapmışlardır. Bu birliktelik savaşın sonuna kadar güçlenerek devam etmiştir.

I. Dünya Savaşı'nın başlangıcını teşkil eden olay; Avusturya İmparatorluğu ve Macaristan Krallığ 1 Prensi Arşidük Fransuva Ferdinand ve eşi Prenses Sophie Saraybosna'da Sırp Milliyetçisi Gavrilo Princip ve ekibi tarafından suikastla öldürülmesidir. Bu olay üzerine Osmanlı Padişahı V. Mehmed Reşad, İmparator I. Franz Joseph'e taziye mektubu göndermiş ve Osmanlı topraklarında Avusturyalıların matem tutmalarına müsaade etmiştir. Yine kısa süre sonra eşinin vefatı dolayısıyla Padişah, İmparatora taziye mesajı göndermiştir (13 Eylül 1914).

Avusturya İmparatoru'nun doğum gününü tebrik için bir heyet İstanbul'daki Avusturya Sefarethanesine gitmiştir (15 Ağustos 1914). Yine aynı gün Karakol Gemisi süslenmiş ve top atışı ile doğum günü tebrik edilmiştir.

Arşidüșes Adelgunde Deoryer'in vefatı üzerine Padişah'ın taziye mektubunu iletmek üzere bir heyet Viyana'ya gönderilmiştir(29 Aralık 1914).

Osmanlı yönetimi tarafindan Avusturya İmparatoru Fransuva Joseph ile Arşidük Şarl Fransuva ve Başkumandan Arşidük Frederik'e altın ve gümüş harp madalyaları verilmiştir (16 Mayıs 1915).

Padişahın ameliyatının başarılı geçmesi üzerine İmparatordan ve yöneticilerden, konsolos ve elçilerden "geçmiş olsun" mesajları gelmiştir(2 Ağustos 1915).

Arşidüşes Mari'nin vefat etmesi nedeniyle Padişah, İmparatora taziye mesaj1 göndermiştir (26 Eylül 1915).

Veliaht Yusuf İzzeddin Efendi'nin vefatı dolayısıyla İmparator I. Fransuva Joseph taziye mektubu göndermiştir (Şubat 1916).

İmparator I. Fransuva Joseph'in vefatı nedeniyle cenaze törenine katılmak üzere Veliaht Vahideddin Efendi başkanlığında bir heyet Viyana'ya gönderilmiş, ayrıca İstanbul'da yapılan dini törene Şehzade Ziyaeddin Efendi başkanlığında bir heyet katılmıştır (Ekim 1916). Yerine geçen Arşidük Fransuva Şarl'ın tahta çıkışını bildirmek üzere Arşidük Maksimilien İstanbul'a gelmiş ve oldukça görkemli törenlerle ağırlanmıştır (Kasım 1916). Ayrıca yeni imparatora Osmanlı nişanı gönderilmiştir.

\footnotetext{
*Doç. Dr.; Afyon Kocatepe Üniversitesi Eğitim Fakültesi İlköğretim Bölümü, sortak33@yahoo.com.
} 
Avusturya-Macaristan İmparatoru I. Fransuva Şarl ve eşi Mayıs 1918'de İstanbul'u ziyaret etmişler ve gayet görkemli törenlerle ağırlanmışlardır.

Padişah V. Mehmed Reşad'ın vefatı üzerine İmparator hem taziye mektubu ve cenaze törenine bir heyet göndermiştir. Daha sonra tahta çıkan VI. Mehmed Vahideddin'in cülusunu tebrik etmiştir (Temmuz 1918).

Osmanlı Devleti ile Avusturya-Macaristan İmparatorluğu arasındaki siyasi, askeri ve ekonomik ilişkilerin oldukça iyi olduğu I. Dünya Savaşı döneminde bu iyi ilişkiler iki hanedan arasındaki münasebetlerin ve dostluk havasının güçlenmesine de yansımıştır. Birçok alanda yapılan anlaşmaların yanında iki hanedan ailesi arasında çok yoğun bir yazışma süreci yaşanmış, taziye, tebrik, taltif amaçlı ziyaret ve yazışmalar yapılmıştır. Bildiride; yukarıda verilen örnek olaylar ve diğer ilişkiler Osmanlı Arşivi'nde tespit edilen belgeler ve araştırma eserlerden yararlanılarak değerlendirilecektir.

Anahtar Sözcükler: Osmanlı Hanedanı, Habsburg Hanedanı, I. Dünya Savaş1, I. Fransuva Jozef, V. Mehmed Reşad, I. Fransuva Sarl, VI. Mehmed Vahideddin.

\title{
RELATIONS BETWEEN HABSBURG AND OTTOMAN ROYAL FAMILIES DURING WORLD WAR I
}

\begin{abstract}
The largest scale war of human history is the first world war, the inevitable result of affairs and several competitions amongst states for several centuries. Ottoman and Austro-Hungarian empires which had struggled against each other for domination in the Balkans directly or in alliances shared a common fate in "central powers" founded by the heading of Germany before the WW-I. This association had been continue till the end of war, by getting stronger.

Assasination of Archduke Franz Ferdinand of Austria and his wife Princess Sophie by ultra nationalist Gavrilo Principe and his team, in Sarajevo, constitutes the beginning of WW-I. After this assasination, Mehmed Resad V, the sultan of Ottoman Empire, sent letter of condolence to Franz Joseph I and allowed Austrian citizens in Ottoman territories to mourn for assassinated archduke and his wife. Sultan also sent another letter of condolence to Franz Joseph for decease of his wife.( 13th of September ,1914).
\end{abstract}

An Ottoman comittee visited Austro-Hungarian Embassy in İstanbul to congratulate birthday of the emperor of Austria and on the same day the patrol vessel of Ottoman Navy was prepared for salvo fire.(15th of August, 1914).

After the decease of Archduchess Adelgunde Deoryer, an Ottoman committee was sent to Vienna to convey the letter of sultan.(29th of December, 1914).

By the Ottoman government, campaign medals was conferred to Emperor Franz Joseph, Archduke Charles, and chief commander Archduke Frederik.(15th of May 1915).

"Get well" messages were sent by Austrian emperor, executives,and ambassadors after surgery of the sultan.(26th of September, 1915). 
A condolence letter of Emperor Franz Joseph-I was conveyed for decease of the crown prince Yusuf İzzettin Efendi.(February 1916).

Due to the decease of Emperor Franz Joseph, a committee with the crown prince Vahideddin Efendi was sent to Vienna to attend to funeral rites, and also another committee with Prince Ziyaüddin Efendi attended to rites in İstanbul.(October 1916).

Archduke Maximillian came to İstanbul in order to notify accession of Charles-I of Austria and he welcomed with magnificent ceremonies, and also Ottoman medal was sent to new emperor.(November 1916)

Austrian Emperor Charles-I and his wife visited İstanbul in May 1918 and they were hosted with magnificent ceremonies.

Due to the decease of Sultan Mehmed Resad-V, the Emperor sent a letter and a committee to attend to rites in İstanbul, and he congratulated enthronement of Mehmed Vahideddin-V.( July 1918).

Good relations between Ottoman and Habsburg royal families caused to get stronger the relations and alliances of these countries during WW-I. In addition to correspondences about many issues, several correspondences and visits were made in order to condolence, congratulate, and gratify.

In notification, specimen events given above and many other affairs will be considered with documents from Ottoman archives and some other resources.

Keywords: House of Ottoman, House of Habsburg, World War I, Franz Joseph-I, Mehmed Resad-V, Charles-I of Austria, Mehmed Vahideddin-VI.

\section{Giriş}

Yüzlerce yıllık biriken sorunların ve oluşan şartların sonucu kaçınılmaz hale gelen I. Dünya Savaşı, insanlığın gördügü ilk büyük dünya savaşı olarak tarihteki yerini almıştır. Uzun y1llar Balkanlarda hâkimiyet mücadelesi veren ve bire bir veya bloklar halinde savaşan Osmanlı ve Avusturya-Macaristan İmparatorlukları bu savaş öncesinde Almanya öncülüğündeki İttifak Devletleri bloğunda yer alarak kader birliği yapmışlardır. Bu birliktelik savaşın sonuna kadar güçlenerek devam etmiştir.

I.Dünya Savaşı öncesinde Avusturya-Macaristan İmparatorluğu'nun yaklaşan savaş ve devletler arası dengeler açısından Osmanlı Devleti'ne ayrı bir önem verdiği görülmektedir. İmparator I. Fransuva Jozef'in (Franz Joseph I) 29 Nisan 1914'te Peşte'de toplanan Temsilciler Meclisi'nin (Parlamento) açılışında Veliaht Arşidük Fransuva Ferdinand (Archduke Franz Ferdinand d'Est) tarafından okunan nutkunda, Osmanlı Devleti ile ilgili olumlu ifadeler yer almaktadır. Osmanlı Devleti'ni Balkan Savaşlarında uğradığı kayıplara rağmen yakın doğuda hâlâ önemli bir unsur olarak nitelendiren İmparator, kısa sürede toparlanabileceğine olan ümidini belirttikten sonra "Devlet-i Aliyye-i Osmaniyenin siyaseten ve iktisaden kesb-i kuvvet 
eylemesine çalışacağız" ifadesini kullanmıştır. Osmanlı Devleti ile siyasi ve ekonomik menfaatlerinin veya ortak siyasi ve ekonomik çıkarlarının bulunduğunu kaydeden İmparator Bâb-1 Âlî ile iyi ilişkilerin geliştirilmesini arzu ettiklerini vurgulamıştır .

I. Dünya Savaşı'nın başlangıcını teşkil eden olay; Avusturya İmparatorluğu ve Macaristan Krallığ Prensi Arşidük Fransuva Ferdinand ve eşi Prenses Sophie'nın Saraybosna'da Gavrilo Princip ve ekibi tarafından suikastla öldürülmesidir (28 Haziran 1914). Arşidük ve eşi, Bosna'da ordu manevralarını izledikten sonra Saraybosna'yı ziyaret ederken bir Bosnalının bombalı saldırısından kurtulmuşlarsa da bir dönemeçte Gavrilo Princip isimli Bosnalı Sırp bir gencin tabancayla ateş açması sonucu hayatını kaybetmiştir. Suikast çetesinin arkasında Sırbistan tarafından desteklenen "Kara el" isimli bir teşkilatın olduğunun belirlenmesi üzerine Avusturya-Macaristan Hükümeti, Sırbistan'a 23 Temmuz 1914 tarihinde ültimatom vermiştir. $\mathrm{Bu}$ ültimatomda; Sırbistan'da Avusturya karşıtı yayınlara ve faaliyetlere son verilmesi, bu faaliyetlere katılanların devlet görevlerinden çıkarılması, suikasta katılanlar hakkında soruşturma açılması ve Avusturya-Macaristan'dan yetkililerin de bu soruşturmalara katılması gibi istekler yer almaktadır. Sırbistan, cevaplandırmak için 48 saatlik süre verilen bu ültimatomu İtilaf Devletlerine danışarak 25 Temmuz'da reddetmiştir. Bunun üzerine yapılan hazırlıklardan sonra 28 Temmuz 1914 günü öğle vakti Avusturya-Macaristan İmparatorluğu Sırbistan'a savaş ilan etmiştir².

Avusturya'nın savaş ilanından sonra İtilaf ve İttifak Devletleri arasında savaş resmen ve fiilen başlamış oluyordu. Bu durumda Osmanlı Devleti de savaşla ilgili politikalarını netleştirmek için girişimlerini hızlandırmıştır. Daha önce özellikle de İtilaf Devletleri nezdinde yürütülen temasların sonuçsuz kalmasından sonra İttifak Devletleri ile görüşmelere ağırlık verilmiştir. Gizlilik içinde yapılan görüşmelerin sonunda 2 Ağustos 1914 günü sabah saatlerinde Almanya ile "tedâfü'î: savunma amaçlı" bir ittifak anlaşması Said Halim Paşa ve Wangenheim arasında imzalanmıştır. Anlaşma gerçekte savunma içerikli olmakla birlikte; "AvusturyaSırbistan arasındaki savaşa Rusya'nın karışması ve Almanya'nın da Rusya ile savaşa girmesi durumunda Osmanlı Devleti'nin de savaşa girmesine" dair ikinci madde, adım adım Osmanlı Devleti'ni savaşa sürükleyen gelişmelerin anahtarı olacaktır. Diğer taraftan Osmanlı-Alman

\footnotetext{
${ }^{1}$ BOA.HR.SYS. D: 171 , G: 70.

${ }^{2}$ Yusuf Hikmet Bayur, Türk İnklâbı Tarihi, C. II/Kısım: IV, Türk Tarih Kurumu Yay., Ankara, 1991, s.558-559, 588-593, 600; Enver Ziya Karal, Osmanlı Tarihi, C. IX, TTK.Yay., Ankara, 1996, s. 365-370.
} 
görüşmeleri sürerken anlaşmanın imzasından saatler önce Almanya ile Rusya arasında savaş hali başlamışt ${ }^{3}$.

Aslında Osmanlı Devleti'ni Almanya ve Avusturya'yla aynı ittifak içine alma önerisi ilk olarak Avusturya'dan gelmiş, ancak ilk etapta Osmanlı Devleti'nin durumu dolayısıyla pek sıcak karşılanmamıştır. 22 Temmuz'da Enver Paşa Avusturya'ya benzer içerikli bir anlaşma teklifinde bulunmuştur. Bu çerçevede Sadrazam Said Halim Paşa ile Avusturya Sefiri Pallavicini arasında bir görüşme de yapılmıştır. Çeşitli aşamalarda sürdürülen görüşmeler sonucunda, Osmanl1Alman İttifak Anlaşması'nı öğrenip tasvip ettiğine dair Avusturya Sefiri ile bir belge imzalanmıştır. Bu belgeden ittifak anlaşmasının Avusturya-Osmanlı arasında da geçerliliği sonucuna ulaşılabilir. Çünkü devletlerle yürütülecek görüşmelere dair irade-i seniyyede geçen "Devlet-i Aliyyemiz ile Almanya devleti arasında akdedilip Avusturya tarafindan da kabul edilmiş olan muahedeyi daha ziyade temin ve tevsî eylemek üzere tecdid için Sadr-1 Azam ve Hariciye Nazırımız Mehmed Said Paşa hazretlerine canib-i seniyy ül-cevânib-i şehriyânemden mezuniyet verilmiştir." ifadesi buna delalet etmektedir ${ }^{4}$.

Diğer taraftan Almanya ve Avusturya'nın Rusya ile savaşa başlamış olduğu dönemde müttefik olarak İtalya'nın da savaşa katılması beklentisi artmış ise de; İtalya Başbakanı Giuliano Giolitti bir açıklama yaparak savaşa girme konusundaki isteksizliklerini ifade etmiş ve bunun da İttifak'a aykırı olmadığını savunmuştur ${ }^{5}$.

Ayrıca Osmanlı Devleti'nin Almanya ve Avusturya'nın savaşa girmemesi için de baskıların arttığı görülmektedir. 9 Ağustos 1914 tarihli İngiliz ve Fransız gazetelerinde İngiliz yöneticilerin; Osmanlı Devleti savaşa girmezse Avrupa ve Küçük Asya'da toprak bütünlüğünün korunacağı, aksi takdirde Çanakkale Boğazı'nın zorlanacağı ve Osmanlı limanlarının bombardıman edileceğine dair haberler yer almıştır. Bu haberler Roma Sefaretinden İstanbul'a Hariciye Nezaretine bildirilmiştir ${ }^{6}$.

$\mathrm{Bu}$ çabalar sonuç vermemiş ve 29 Ekim 1914'te yaşanan ve "Karadeniz vak'a-y1 harbiyesi" olarak bilinen olayın (Karadeniz'de Rus donanması ile çatışma ve Odesa ve Batum

\footnotetext{
${ }^{3}$ Yusuf Hikmet Bayur, Türk Inkılâbı Tarihi, C.II/Kısım IV, TTK. Yay., Ankara, 1991, s. 629-643; Âli Fuad Türkgeldi, Görüp Isşittiklerim, TTK.Yay., Ankara, 1987, s.115-116. Anlaşmanın orijinal metni için bakınız: Veli Y1lmaz, 1 inci Dünya Harbi'nde Türk-Alman İttifakı ve Askeri Yardımlar, İstanbul, 1993, s.65-66, 248-249. ${ }^{4}$ Yusuf Hikmet Bayur, Türk İnkılâbı Tarihi, C.II/Kısım IV, s. 629, 635, 646-647; Âli Fuad Türkgeldi, a.g.e., s. 115. ${ }^{5}$ BOA.DH.EUM.5.Şb. D: 7, G: 1.

${ }^{6}$ BOA.DH.EUM.5.Şb. D: 18, G: 31-R.
} 
Limanlarının bombalanması) neticesinde Osmanlı Devleti kendini hiç de hazır olmadığı bir savaşın içinde bulmuştur ${ }^{7}$.

Birlikte savaşan iki devletin kader ortaklığı iki ülke halkını da "başarıya sevinçte ve başarısızlıkta üzüntüde" birbirine yakınlaştırmıştır. Örneğin Irak Cephesi'nde 29 Nisan 1916 tarihinde kazanılan Kutü'l-Amare Zaferi Avusturya'da da büyük sevince neden olmuş, Viyana caddeleri bayraklarla donatılmış, devlet yöneticileri ve halk, Osmanlı Sefaretine tebrik ziyaretinde bulunmuştur. Buna karşılık Padişahın teşekkür mesajı yetkililere iletilmiştir (13 May1s 1916) $)^{8}$.

27 Ağustos 1916 tarihinde Romanya'nın Avusturya-Macaristan'a savaş ilan etmesinden sonra diğer müttefiklerle birlikte Osmanlı Devleti de Romanya'ya savaş ilan etmek durumunda kalmıştır. Konu Meclis-i Vükelâ'da görüşülmüş ve "diğer müttefiklerimiz Almanya ve Bulgaristan Hükümetlerinin Devlet-i Romanya'ya i'lan-1 harb eylemeleri takdirinde Hükümet-i Seniyyenin de müştereken hâl-i harbe girmesi menafi'-i mahsusamız icâbâtından olmasıyla......" ifadesiyle Romanya'ya karşı savaşa girilmesi kararı alınmıştır. Bununla ilgili irade-i seniyye Pa 29 Ağustos 1916'da çıkmıştır'.

I. Dünya Savaşı sırasında Avusturya askerleri Osmanlı cephelerinde savaştığı gibi Osmanlı askerleri de Rusya'ya karşı Galiçya Cephesi'nde Avusturya saflarında savaşmışıtır. Bu savaşlarda şehit olan askerlerimiz için Avusturya (Raab), Polonya (Krakov), Macaristan (Budapeşte) ve Çekoslovakya"da (Hodonin, Pardubice, Walasske) şehitlikler yapılmıştır ${ }^{10}$. Savaş sırasında 21 Kasım 1916'da Avusturya'da taht değişikliği olmuş ve I. Şarl başa geçmiştir. Avusturya'nın farklı etnik grupların sebep olduğu iç sorunları ve cephelerdeki durumu dikkate alan yeni İmparator, Almanya, Osmanlı Devleti ve Bulgaristan'dan ayrı olarak İtilaf Devletleri ile bir barış yapmayı düşünmüştür. Bu sebeple Kayınbiraderi olan eski Fransız Kraliyeti hanedanından Bourbon Parme Prensi Sixte'i (o sırada Belçika Ordusunda subay olarak görev yapmaktadır) İsviçre'ye çağırtır. Görüşmede Prens Sixte'e bir barış anlaşması için kendisini Fransa'yla görüşmekle görevlendireceğini söylemiştir. Prens Sixt bu çerçevede 11 Şubat 1917 tarihinde Dış işleri Bakanlığ 1 Sekreteri Jules Cambon'la Paris'te görüşmüştür. Bu görüşmede; İstanbul'un Ruslara verilmesine Avusturya'nın sessiz kalması, Belçika ve Alsas-Loren'in

\footnotetext{
${ }^{7}$ Birinci Dünya Harbinde Türk Harbi, c.I, Genelkurmay ATASE Başk. Yay., Ankara, 1991, s. 216-220; Kâzım Karabekir, Birinci Cihan Harbine Nasil Girdik, c. II, Emre Yay., İstanbul, 1995, 360-367.

${ }^{8}$ BOA.DUIT. D: 12, G: 61.

${ }^{9}$ BOA.MV. D: 244, G: 77.

${ }^{10}$ http://www.msb.gov.tr/Sehitlikler/YurtDisiSehitlikleri (19.01.2016).
} 
Almanya tarafından bırakılması vs. şartlar dâhilinde Avusturya'nın barış önerisi Fransa'ya iletilmiş oluyordu. Prens Sixte, İmparatorun bu hususları içeren bir beyanname yayınlamasını gündeme getirmişse de Rusların İstanbul'a hâkim olmalarının Balkanlardaki Avusturya menfaatlerine aykırı olması nedeniyle Avusturya Dış işleri Bakanı karşı çıkmıştır. Yayınlanacak beyanname ile ilgili görüşmeler sürerken, Rusya'da ihtilal başlayınca bu barış girişimi de rafa kaldırılmıştır ${ }^{11}$.

ABD'nin Almanya'ya savaş ilan ederek harbe dahil olmasından sonra AvusturyaMacaristan İmparatorluğu bu ülke ile diplomatik temaslarını kesmiştir. İttifak Anlaşması'na uygun olarak ve müttefikliğin gereği olarak Osmanlı Devleti de ABD ile ilişkilerin kesilmesine karar vermiştir (18 Nisan 1917) ${ }^{12}$.

Osmanlı Devleti ile Avusturya-Macaristan İmparatorluğu arasındaki ilişkilerde iki ülke arasında yapılan ticaret önemli bir yer tutmaktaydı. Bu ticari ilişkileri daha da arttırmak amacıyla 1917 yılında yeni bir ticaret anlaşması imzalanması gündeme gelmiştir. Bu çerçevede İstanbul'da yapılacak olan görüşmelere Osmanlı Devleti adına Maliye Nazırı Cavid Bey ve Hariciye Nezareti Umur-1 İdariye Müdir-i Umumîsi Suad Bey'in katılması Heyet-i Vükelâ'ca kararlaştırılmış ve buna dair irade-i seniyye 20 Aralık 1917 tarihinde onaylanmıştır ${ }^{13}$.

Savaşın son yılı iki ülke devlet arasındaki ilişkilerin iyi olması çeşitli alanlarda imzalanan anlaşmalarla meyvelerini vermiş oluyordu. Yapılan görüşmelerden sonra 12 Mart 1918 tarihinde Viyana'da Osmanlı Devleti ile Avusturya-Macaristan İmparatorluğu arasında; Şehbenderlik Mukavelenamesi, İkamet Mukavelenamesi, Mevadd-1 Hukukiyede Himaye-i Adliye ve Devair-i Adliye Beyninde Muavenet-i Mütekabile Hakkında Mukavelename, İade-i Mücrimin Muahedenamesi ile Kuvve-i Müsellaha-i Berriye ve Bahriyeden Davete İcabet Etmeyenlerle Firarilerin Mütekabilen Teslimleri Hakkında Mukavelename imzalanmıştır. Meclis-i Mebusan ve Ayan'da aynen kabul edilen bu anlaşmaların teatisine ve tatbikine dair irade-i seniyye 8 Nisan 1918 tarihinde çıkmıştır ${ }^{14}$.

Uluslararası ilişkilerde de müttefikler arasında işbirliği devam etmiştir. İttifak Devletleri ile Rusya arasındaki mütareke görüşmelerine Osmanlı Murahhası olarak Alman Ordugâhı'ndaki

\footnotetext{
${ }^{11}$ Yusuf Hikmet Bayur, Türk İnklâbı Tarihi, C. III/Kısım: III, Türk Tarih Kurumu Yay., Ankara, 1991, s.515-517.

${ }^{12}$ BOA.MV. D: 247, G: 31.

${ }^{13}$ BOA.İ.DUIT. D: 37, G: 25.

${ }^{14}$ BOA.İ.DUIT. D: 35, G: 10; BOA.MV. D: 211, G: 137.
} 
temsilci I. Ferik Zeki Paşa tayin edilmiştir (11Aralık 1917) ${ }^{15}$. Daha sonra Rusya ile yapılacak barış görüşmeleri için Sadrazam Talat Paşa başkanlığında, Berlin Sefiri Hakkı Paşa, Hariciye Nazırı Ahmed Nesimi Bey ve Padişah Yaverlerinden I. Ferik Zeki Paşa'dan oluşan bir heyetin gitmesi kararlaştırılmıştır (18 Aralık 1917) ${ }^{16}$. Aynı şekilde İttifak Devletleri ile Romanya arasında yapılacak barış görüşmelerinde Osmanlı Devleti'ni Hariciye Nazırı Ahmed Nesimi Bey ile Heyet-i Ayan üyelerinden I. Ferik İzzet Paşa'nın katılması kararlaştırılmıştır (23 Şubat $1918)^{17}$.

Ayrıca savaşın son yılında Osmanlı Devleti, Almanya, Avusturya-Macaristan ve Bulgaristan ile Sovyet Rusya arasında imzalanmış olan Brest-Litovsk Anlaşması ve İttifak Devletleri ile Ukrayna arasında imzalanmış olan Barış Anlaşması Padişah tarafından tasdik edilmiştir (17 Nisan 1918) ${ }^{18}$.

ABD'nin savaşa İtilaf Devletleri safında savaşa girmesi, Osmanlı Devleti ve Avusturya'da çözülme ve benzeri sebeplerden dolayı 1918 sonbaharına doğru yaklaşık 4 yıl süren savaş İttifak Devletleri aleyhine gelişmekteydi. Osmanlı Devleti ve Almanya'nın 1srarlarına rağmen Avusturya Hükümeti 14 Eylül 1918 tarihinde ateşkes isteğini İtilaf Devletlerine iletmişse de ilk etapta karşılık bulmayacaktır. 7 Ekim'de aynı yönde ABD'ye başvuran Avusturya bu amacına ancak 3 Kasım'da ateşkes imzalayarak savaştan çekilecektir. Diğer bazı girişimlerden sonuç alamayan Osmanlı Devleti ve Almanya da 5 Ekim'de ABD'ye Wilson ilkeleri çerçevesinde barışa hazır olduklarını iletmişlerdi. Ahmet İzzet Paşa'nın Sadaret'e gelmesinden sonra Osmanlı Devleti, kendi elinde esir bulunan General Townshend aracılığıyla İngiltere nezdinde de girişimlerde bulunmuş ve 30 Ekim 1918'de Mondros Mütarekesi ile savaştan yenik ayrılmıştır ${ }^{19}$.

\section{1- Ziyaretler}

Osmanlı Devleti ile Avusturya-Macaristan İmparatorluğu arasındaki dostane ilişkilerin zirve noktası sayılabilecek olay, Avusturya İmparatoru ve Macaristan Kralı ve eşinin İstanbul'u ziyaret etmeleridir. Savaşın sonlarına doğru gerçekleşecek bu ziyaret için ciddi hazırlıklar

\footnotetext{
${ }^{15}$ BOA.İ.DUİT. D: 37, G: 29; BOA.MV. D: 248, G: 59.

${ }^{16}$ BOA.İ.DUIT. D: 37, G: 30; BOA.MV. D: 248, G: 59 (Mükerrer).

${ }^{17}$ BOA.İ.DUİT. D: 37 , G: 26

${ }^{18}$ BOA.İ.DUIT. D: 35 , G: 16

${ }^{19}$ Yusuf Hikmet Bayur, Türk Inkılâbı Tarihi, C. III/Kısım: IV, Türk Tarih Kurumu Yay., Ankara, 1991, s.677, 719746, 851-856; Enver Ziya Karal, age., s. 557-860.
} 
yapılmıştır. Ziyaret için hazırlanan program Sadaret'ten Padişah'a arz edilmiş ve tasdik edilmiştir(16 Mayıs 1918). Bu program göre ziyaret şu aşamalarda tamamlanacaktır ${ }^{20}$.

1- İmparator ve beraberindeki heyet Çerkezköy İstasyonu'nda Edirne Valisi, Kumandan ve diğer yetkililerce karşılanacaktır. Selamlama resmi ve askeri tören icra edilecek ve Avusturya-Macaristan marşı çalınacaktır.

2- Şehzade Hayreddin Efendi, Viyana Sefiri Hüseyin Hilmi Paşa, Başkumandan Vekili ve Yaver-i Hâss-1 Şehriyarî Enver ve mihmandar Rıfat ve İzzet Paşalar ile diğer görevlilerden oluşan bir heyet Ayastefanos İstasyonu'nda Padişah adına İmparatoru karşılayacaklardır. Bu törene askeri ve mülki erkân tören kıyafetleri ile katılacaklar, Avusturya-Macaristan Marş1 çalınacaktır. Avusturya-Macaristan'ın İstanbul Sefiri, Askeri Murahhası General Pamyankovski ve Ateşanavali Mösyö Şantaler de Ayastefanos'taki törenlere katılacaklardır.

3- İmparator ve beraberindekileri taşıyan özel tren 19 Mayıs 1918 Pazar günü öğleden sonra saat 4.20'de İstasyonunda olacağından; Padişah, seryaverler, serkâtipler ve diğger erkân da Saraydan İstasyona gideceklerdir.

4- Veliaht Vahideddin, şehzadeler Abdülmecid, Hayreddin, Ömer Hilmi ve Abdülhalim Efendiler, Sadrazam, Mısır Hidivi, Şeyhülislam, Ayan ve Mebusan Meclislerinin Reisleri, Vükela (bakanlar), Ayan ve Mebusandan bir heyet, Sadaret ve Nezaret müsteşarları, Harbiye ve Bahriye Nezaretlerinden heyetler, Polis Müdir-i Umumisi, Şehremini Vekili, İstanbul Vali Vekili ve davet edilecek diğer kişiler İstasyonunda hazır bulunacaklardır.

5- Törene katılacaklar büyük üniformalarını (tören elbiseleri) giymiş olacaklar, Osmanlı ve Avusturya-Macaristan (varsa) nişanlarını takmış bulunacaklardır.

6- İmparator ve beraberindekileri taşıyan tren Sirkeci İstasyonu'na geldiğinde vagonun önünde Padişah tarafindan beyan-1 hoş-âmedî (hoş geldin) edilecektir. Padişah ve İmparator heyetlerindekileri takdim ettikten sonra askeri kıta selamlanacaktır.

7- Takdim merasiminden sonra Padişah İmparator ile İmparatoriçe de Veliaht ile dörder atlı saltanat arabalariyla Sarayın Merasim Dairesine gidilecektir. Arabalar belirlenen yere geldiklerinde top atışları ile selamlama yapılacaktır. Başkumandan Vekili ve Seryaver Enver

\footnotetext{
${ }^{20}$ BOA.İ.DUIT. D: 16, G: 6; BOA.MV. D: 212, G: 27. Ziyaret sırasında yapılacak harcamalar için Teşrifat Dairesine 14.500 kuruş ve mihmandar tayin edilen Fuad Bey'e 2.500 kuruş ek ödenek verilmesi kararlaştırılmıştır (2 Haziran 1918). BOA.MV. D: 212, G: 45.
} 
Paşa Padişah'ın arabasında ve karşısında oturacak, Mihmandar Rıfat Paşa İmparatoriçe'nin arabasında bulunacaklardır.

8- İmparator'un heyetindekiler ve Osmanlı heyetindekiler belirlenen sıra ile arabalara binip Saraya gidilecektir.

9- Gerek karşılama töreni ve gerekse atlı arabalarla yapılacak yürüyüş için birer kroki hazırlanacaktır.

10- Merasim Dairesine gelindiğinde Saray Muhafız Taburundan bir piyade bölüğü tarafından selamlama töreni gerçekleştirilecek ve bu sırada İmparatora ait sancak göndere çekilecektir. Saray Muzikası Avusturya-Macaristan Marşını çalacaktır. Saraydaki üst yöneticiler tarafından da karşılama töreni ifa edilecektir.

11- Merasim Dairesi'nde bir müddet istirahat ve mülakat gerçekleştirildikten sonra Padişah Dolmabahçe Sarayı'na avdet edecektir.

12- Aynı gün saat 6.30 'da İmparator ve İmparatoriçe; Veliaht Vahideddin, Şehzade Abdülmecid Efendi, daha sonra Sadrazam, Mısır Hidivi, Şeyhülislam, Ayan ve Mebusan Reisleri, Vekilleri (bakan) kabul edeceklerdir. Akşam saat 8.00'de Merasim Dairesi'nden hareketle Dolmabahçe Sarayı'na gelerek Padişah'ı ziyaret edeceklerdir. Burada İmparator şerefine özel bir ziyafet düzenlenecektir. Bu ziyafette sivil devlet adamları İstanbulin giyecekler Osmanlı ve Avusturya (varsa) nişanlarını takacaklardır. Askeri yetkililer büyük üniformalarını giyeceklerdir. Ziyafet sırasında Saray Orkestra'sı müzik dinletisi sunacaktır.

İmparator ve İmparatoriçe bu ziyafete otomobil ile geleceklerdir. Saraya gelişlerinde piyade bölüğü tarafından askeri selamlama töreni icra edilecektir. Sadrazam, Vekiller, Saray yetkilileri İmparator ve İmparatoriçe'yi binek taşında karşılayacaklardır. Padişah ise sofada karşılayacak ve birlikte üst kata çıkılacaktır. Dinlenmeden sonra yemek salonuna geçilecektir. Yemekten sonra tekrar yemekten önceki salona geri dönülecektir. İmparator ve beraberindekiler Saraydan Merasim Dairesine gelişteki gibi törenle uğurlanacaktır.

13- İkinci Pazartesi günü sabahleyin saat dokuz civarında İmparator ve beraberindekiler Beyoğlu Santa Marya Kilisesindeki dini törene katılacaklardır. Daha sonra Topkapı Sarayı ziyaret edilecek ve burada Hazine-i Hâssa-i Şahane Müdir-i Umumisi ve diğer yetkililer tarafından karşılanacak olan misafirler öğle yemeğini de burada Merasim Dairesi'nde yiyeceklerdir. 
14- Öğleden sonra saat iki buçukta Padişah, Topkapı Sarayı'na gelecek ve Merasim Dairesi'nde İmparator'a "Osmanlı Müşirliği" payesini ve buna ilişkin menşur ve kılıcı tevdi edecektir. İmparator, saat üç buçukta Malta Kasri'nda Veliaht Vahideddin ve daha sonra Çadır Köşkü'nde Şehzade Abdülmecid Efendi'ye iade-i ziyarette bulunacaktır. Saat dört buçukta Avusturya Sefarethanesinde İmparator bir kabul töreni gerçekleştirecektir. Aynı günün akşamında Padişah, İmparator onuruna Dolmabahçe Sarayında ziyafet verecektir.

İmparator dört atlı saltanat arabasıla mihmandarlar ve maiyeti ile birlikte saat yedi buçukta Merasim Dairesi'nden hareketle Dolmabahçe Sarayı'na gelecek ve askeri törenle karşılanacaktır. Muzıka-1 Hümayun Avusturya Marşını çalacak, Sadrazam, Mısır Hidivi, Şeyhülislam, Hey'et-i Vükela üyeleri, Ayan ve Mebusan Reisleri, Mabeyn-i Hümayun yetkilileri Binek Taşı'nda İmparatoru karşılayacaklardır. Padişah, İmparatoru Sofada karşılayacak ve birlikte üst kattaki Daire-i Mahsusa'ya geçeceklerdir. İmparator ve İmparatoriçe bu odanın bitişindeki salonda yabancı elçileri kabul edecekler ve buradan birlikte ziyafet salonuna geçilecektir. Padişah, İmparator ve davetliler ziyafet salonuna geçerken Muzıka-yı Hümayun Avusturya-Macaristan Marşı'nı ve Marş-1 Sultani'yi çalacaktır.

Yemekten sonra Padişah ve İmparator Daire-i Mahsusa'ya geçecekler ve diğer davetliler Büyük Salona alınacaktır. Bir müddet istirahattan sonra Padişah ve İmparator birlikte davetlilerin bulunduğu Büyük Salona teşrif edeceklerdir. Burada ziyafette davetliler büyük üniforma giyip, Osmanlı ve Avusturya-Macaristan nişan ve kordonlarını, yabancı elçiler kendi devletlerinin nişanlarını takacaklardır. Üniforması olmayanlar İstanbulin giyeceklerdir. Ziyafetten sonra İmparator ve İmparatoriçe Merasim Dairesine avdet edeceklerdir.

15- Ziyaretin üçüncü günü olan 21 Mayıs 1918 Salı günü İmparator ve İmparatoriçe sabah saat sekiz buçukta Taksim'de Avusturya-Macaristan askerlerini teftiş ettikten sonra cami ve müzeleri ziyaret edeceklerdir. Öğle yemeği Merasim Dairesi'nde yenilecektir. Öğleden sonra saat üçte Boğaziçi'nde bir gezinti yapılacaktır. İmparator ve İmparatoriçe bu gezintiyi Söğütlü Vapuru ve yedi çifte Saltanat Kayığı ile, Padişah da on çifte Saltanat Kayığı ve saraya mahsus diğer filika ve kayıklarla gerçekleştirecektir. Aynı gün akşam İmparator ve İmparatoriçe Avusturya Sefarethanesinde akşam yemeğini yedikten sonra veda için Dolmabahçe Sarayı'na gelecekler ve buradan Padişahla birlikte yine karşılamada olduğu gibi törenlerle Sirkeci Garı'na gidilecektir. Uğurlama törenlerinde karşılamadaki merasimler aynen icra edilecektir. 
19 Mayıs 1918 akşamı Dolmabahçe Sarayında yukarıda belirtilen programa uygun olarak (12.madde) Padişah tarafindan İmparator ve İmparatoriçe onuruna hususi bir ziyafet tertip edilmiştir. 20 Mayıs akşamı yine Dolmabahçe Sarayında resmi bir ziyafet (programda 14.madde) düzenlenmiştir. Yemek esnasında Padişah ve İmparator birer konuşma yapmışlardır. Ali Fuad (Türkgeldi) Bey'in gözlemlerine göre; Padişah alışıldığı üzere ağır ağır ve titrek bir sesle konuşmasını yaparken İmparator yüksek sesle ve irticalen Fransızca bir nutuk irad etmiştir. Merasim sırasında İmparator'un tercümanlığını Seryaver Salih Paşa, İmparatoriçe'nin tercümanlığını İsmail Cenânî Bey yapmışlardır. Daha sonra hep birlikte Muayede Salonu'na geçilmiş ve buradaki resmi törene, iki devlet erkânının yanında İstanbul'da bulunan yabancı elçiler de katılmışlardır. Bu ziyafet akşamında Muayede Salonu, Sarayın etrafı ve Boğaz süslenmiş ve aydınlatılmıştır. İmparator bu parlak karşılamadan oldukça memnun olmuştur. Ziyaretin sonunda Ali Fuad Bey'in İmparator'un Saray Nazırı Kont Esterhazi'ye İmparatorun ziyaretten memnun kalıp kalmadığına dair sorusuna verilen cevap şöyledir: "Non seulement il a été content, mais il a été enchanté: Memnun olmak şöyle dursun, mest oldu"21.

19 Mayıs 1918 günü saat on bir buçukta İmparator ve İmparatoriçe'yi taşıyan özel tren Edirne'de Osmanlı sınırlarına ulaşmış ve törenle karşılanmıştır. Yaklaşık 54 saat süren bu gezi yukarıda bahsedilen program dahilinde gerçekleşmiş ve misafirler Sirkeci Tren Garı, Ayastefanos İstasyonu ve Edirne'de de törenlerle uğurlanmıştır. Bu gezi sırasında yaşananlar basında da geniş bir şekilde yer almıştır ${ }^{22}$.

İmparator'un ziyareti sırasında mihmandarlığını Ayan üyesi ve eski Harbiye Nazırlarından İzzet Paşa ve Paris Sefiri Rıfat Paşa yürütmüşlerdir ${ }^{23}$. Programın birinci maddesine uygun olarak Edirne Valisi başkanlığında kalabalık bir heyet ile Avusturya'nın İstanbul Sefaretinden bir heyet Çerkezköy İstasyonu'na giderek İmparator’u resmi karşılamıştır

\footnotetext{
${ }^{21}$ Ali Fuad Türkgeldi, Görüp İşittiklerim, TTK.Yay., Ankara, 1987, s. 132-133. Ali Fuad Bey Hatıralarında ilginç bir diplomasi krizine değinmektedir. Ziyaret programı (7.madde) hazırlanırken; istasyondaki karşılamadan sonra arabalara binilip saraya gidileceğinde protokol kuralları gereği ilk arabada İmparatoriçe ve Padişah, ikinci arabada İmparator ve Veliaht Vahideddin'in yer alması gündeme gelmiştir. Padişah Başmabeyinciyi çağırarak "bu yaştan sonra genç bir İmparatoriçe ile aynı arabaya binip, halkı kendime güldüremem" diyerek değişiklik yapılmasını istemiştir. Onun itirazları üzerine Başkâtip Ali Fuad Bey'den bu konuyu halletmesini istemiştir. Avusturya Sefareti heyetiyle toplantı odasına giden Ali Fuad Bey Padişah'ın bu isteğini bildirince Sefaret Müsteşarı "Avusturya kanunu mucibince merâsimde zaten İmparator, İmparatoriçeye tekaddüm eder (önce gelir); İmparatoriçe yalnız ziyafetlerde nezaketen İmparator'a takdim edilir (önce gelir), Arzû-yı şahâne veçhile yaparız" cevabını vermiş ve böylece sorun çözülmüştür. $B k$ : Aynı yer.

${ }^{22}$ Mücahit Özçelik, "Avusturya İmparatoru ve Macaristan Kralı'nun 1918 İstanbul Ziyaretinin Türk Basınına Yansımaları", Süleyman Demirel Üniversitesi Fen Edebiyat Fakültesi Sosyal Bilimler Dergisi, Sayı: 27 (Aralık 2012), s.51-63.

${ }^{23}$ BOA.MV. D: 212 , G: 113.
} 
(19 Mayıs 1918) ${ }^{24}$. İmparator'un İstanbul'a trenle geliş ve dönüşü masrafı olarak Demiryolu Şirketine 280.601 kuruş ödenmiştir ${ }^{25}$. İmparator ve İmparatoriçe sarayda misafir edilmişler, Dış işleri Bakanı Kont Buryan İmparatorun maiyetindeki diğer kişiler için Pera Palas'ta apartman kiralanmıştır ${ }^{26}$.

Avusturya İmparatoru ve Macaristan Kralı I. Jozef'in ölümü ve yerine I. Şarl'ın geçmesi (21 Kasım 1916) iki devlet ve iki hanedan arasında yazışma ve ziyaretlerin artmasına sebep olmuştur. Yeni İmparator'un tahta çıkışını bildirmek üzere kardeşi Arşidük Maksimilyan'ın İstanbul'u ziyareti kararlaştırılmıştır. Avusturya Sefaretinden; Arşidük Maksimilyan'ın 19 Şubat 1917 tarihinde İstanbul'a geleceği ve heyette Süvari General Kont Loney, Sefaret Müsteşarı Kont Konstantin Deim, kendi teşrifatçısı Kont Fransuva Seşi ve Saray Müdürü Kont Konsolati'nin bulunacağı bildirilmiştir. Bunun üzerine Hariciye Nezaretinden 5 Şubat 1917 tarihinden Sadaret'e gönderilen yazıda; bu tarihte ziyaretin uygun olup olmadığının Saray'dan sorulduğu belirtildikten sonra icra edilecek teşrifat merasiminin tespiti ve mihmandar tayini ile yapılacak karşılama töreninde görevlendirileceklerin bildirilmesi hususu dile getirilmiştir. Hazırlanan program taslağı Sadaretçe Saray'a arz edilmiş ve tasdik edilmiştir (10 Şubat 1917). Arşidük'ün mihmandarlığına Mirliva Ziya Paşa ve Teşrifat Müdür Muavini Fuad Bey ile Seryaver-i Hazret-i Şehriyarî Binbaşı Salih Bey tayin edilmiştir. Yapılan ziyaret programına göre; 19 Şubat Pazartesi sabahı Ziya Paşa ve beraberindeki heyet karşılama için Çekmece İstasyonu'na gidilecek, İstasyonunda Şehzadelerden biri ve Teşrifat Müdürü Memduh Bey Arşidük'ü karşılayacak ve askeri tören yapılacaktır. Buradan ikametine tahsis edilen Yıldız Sarayı'na geçecek olan Arşidük Maksimilyan'a Serkarîn tarafından Padişah'ın selam ve iyi dilekleri iletilecek ve öğleden sonra da Padişah tarafından Dolmabahçe Sarayında kabul edilecektir. Buraya geliş gidişlerde askeri tören icra edilecektir. Daha sonra Padişah Merasim Dairesine Arşidük'e iade-i ziyarete gidecek ve akşam da Arşidük şerefine özel bir ziyafet verecektir. Bu ziyafete Sadrazam, Harbiye ve Hariciye Nazırları, Avusturya Sefiri ile Padişah'ın ve Arşidük'ün maiyetleri de katılacaklardır. Salı günü Arşidük'ün iade-i ziyaretleri ile geçecek, Çarşamba akşamı yine Padişah'ın vereceği ziyafetle tamamlanacaktır. Arşidük'ün ziyareti

\footnotetext{
${ }^{24}$ BOA.DH.ŞFR. D: 87, G: 165, BOA.DH.ŞFR. D: 87, G: 171; BOA.DH.KMS. D: 44-2, G: 9. Karşılama töreni için Tahsisat-1 Mestureden 7755 kuruş harcama yapılmıştır.

${ }^{25}$ BOA.MV. D: 212, G: 124.

${ }^{26}$ BOA.MV. D: 212, G: 57. Bu mazbataya göre kira ve yemek masrafı olarak Teşrifat Dairesi'nce 95.665 kuruş ödendiği anlaşılmaktadır.
} 
sırasında Harbiye Nezaret üç otomobil, İstabl-1 Âmire araba ve otomobil ve Bahriye Nezareti bir istimbot hazır edeceklerdir ${ }^{27}$.

Avusturya-Macaristan İmparatorluğu veliahtı Arşidük Maksimilyan İstanbul'u ziyareti sırasında Yıldız Sarayı'nda misafir edilmiştir. Bu ziyaret esnasında gösterilen ilgi ve dostluğa bir teşekkür mahiyetinde İmparator tarafından Şehzade Ömer Hilmi Efendi ve Mabeyn-i Hümayun yetkililerinden on kişiye nişan verilmiştir (14 Nisan 1917) ${ }^{28}$.

Yine Avusturya İmparator Hanedanına mensup Veliaht Arşidük Huber Salvator 1917 yılında Beyrut ve Şam'ı ziyaret etmiştir. Bu ziyaret sırasındaki misafirperverlik ve hizmetleri dolayısıyla Suriye ve Beyrut Polis Müdürlüklerinde görevli 11 kişi İmparator tarafından çeşitli nişanla taltif edilmiştir ${ }^{29}$.

\section{2- Tebrikler, Nişan ve Diğer Hediye Takdimleri}

İki hanedan arasındaki yazışmaların ve dostluk gösterilerinin en önemli alanlarından birisini de sevinçlerin paylaşılması ve kederli günlerdeki dayanışma oluşturmuştur. Ayrıca çeşitli vesilelerle nişan ve hediye takdimi gerçekleşmiştir.

Osmanlı Hükümeti, savaşın başladığı dönemde ittifaka katılma aşamasında İmparator Fransuva Jozef'in doğum gününde bir jest yapmaya karar vermiştir. Sadaret'ten Bahriye Nezaretine gönderilen bir yazıda; İmparator'un doğum günü olan 18 Ağustos 1914 Salı günü Karakol Gemisi'nin donatılması ve belirlenen vakitte top atışları yapılması emrini tebliğ etmiştir (13 Ağustos 1914). Ayrıca Padişah adına yüksek rütbeli memurlardan oluşan bir heyet Avusturya'nın İstanbul Sefarethanesine giderek tebrik ziyaretinde bulunmuş ve İmparator' a kutlama telgrafı çekilmiştir. Aynı kutlamalar 1915 yılında da tekrarlanmıştır ${ }^{30}$.

İki Hanedan arasındaki jestler karş1lıklı olmuştur. Kısa bir süre önce Osmanlı Devleti'nden Avusturya'ya geçmiş olan Bosna'nın merkezi Saraybosna'daki "Kareva Ulika (Careva Ulica): İmparator Caddesi" isimli caddenin adının değiştirilerek Padişah V. Mehmed Reşad'ın adı verilmesi gündeme gelmiştir. Bununla ilgili olarak Saraybosna Şehir Meclisi'nin 17 Kasım 1914 tarihli toplantısında oy birliği ile alınan karar Avusturya-Macaristan Hükümeti'ne bildirilmiş ve iki Hükümet arasındaki yazışmalar başlamıştır. Konunun Avusturya Sefaretinden

\footnotetext{
${ }^{27}$ BOA.İ.DUİT. D: 1, G: 70; BOA.MV. D: 206, G: 29; BOA.BEO. D: 4454, G: 334043.

${ }^{28}$ BOA.İ.DUIT. D: 72, G: 24; BOA.BEO. D: 4464, G: 334761.

${ }^{29}$ BOA.İ.DUIT. D: 72 , G: 68 .

${ }^{30}$ BOA.BEO. D: 4305, G: 322821; BOA.İ.MBH. D: 16, G: 34; BOA.İ.MBH. D: 16, G: 50; BOA.İ.MBH. D: 18, G: 33.
} 
Osmanlı Hariciye Nezaretine bildirilmesi üzerine Nezaret'ten Sadarete 12 Aralık 1914 tarihinde yazılan arizada; Avusturya geleneklerine göre böyle bir isimlendirme yapılması, ismi verilecek kişinin muvafakatine bağlı olduğundan Padişah'tan müsaade alınması talep edilmiştir. Bununla ilgili Padişahın müsaadesi alınmış ve gerekli yazışmanın yapılması Hariciye Nezaretine bildirilmiştir (15 Aralık 1914) $)^{31}$.

İki hükümdarın jestleri özel günlerin kutlanmasıyla da devam etmiştir. Avusturya İmparatoru ve Macaristan Kralı I. Şarl, Sultan V. Mehmed Reşad'ın tahta çıkış yıldönümü olan 27 Nisan 1917 tarihinde Osmanlı Devleti'nin Viyana Sefaretindeki görevlilere bir kutlama ziyafeti tertip etmiştir. Bu ziyafet ve diğer görüşmelerden bu kutlamanın her yıl tekrarlanacağ anlaşıldığından, buna bir jestle karşılık verilmesi gündeme gelmiştir. $\mathrm{Bu}$ cümleden olarak I.Şarl'ın doğum günü olan 17 Ağustos 1917 tarihinde Padişah tarafından Avusturya'nın İstanbul Sefaretindeki görevlilerden oluşan heyete bir ziyafet tertip etmesi kararlaştırılmıştır (29 Mayıs $1917)^{32}$.

Arşidük Şarl Fransuva ve Prenses Zita'nın oğlu Arşidük Robert'in doğumu (8 Şubat 1915) nedeniyle Padişah, İmparator Fransuva Jozef'e bir mektup göndererek duyduğu sevinci ifade etmiştir (29 Mart 1915) ${ }^{33}$.

Çanakkale Zaferi iki müttefik devlet açısından savaşın gidişatı için sevinç vesilesi olmuştur. Avusturya İmparatoru ve Macaristan Kralı, Harbiye Nazırı Enver Paşa'ya Birinci ve Bahr-i Sefîd Kumandanı Cevad Paşa'ya İkinci rütbeden Merit Militer nişanları hediye etmiştir $(20 \text { Nisan 1915) })^{34}$.

Padişah V. Mehmed Reşad'ın ameliyatının başarılı geçmesi ve sağlı̆̆ına kavuşması, yurt içinde olduğu kadar yurt dışında da yankı bulmuştur. Avusturya-Macaristan Kızılhaç Cemiyeti Reisi Prenses Lihtenştayn (Liehtenstein), Padişah'a geçmiş olsun dileklerini içeren bir mektup göndermiş ve Padişah'ın teşekkür ve memnuniyetini ifade eden cevap verilmiştir (22 Temmuz $1915)^{35}$.

31 Mayıs 1916'da Arşidük Karl ve Arşidüşes Zita Bourbon'un oğlu Arşidük Felix'in doğumunu bildiren İmparator Fransuva Jozefin mektubu İstanbul'daki Avusturya Sefareti

\footnotetext{
${ }^{31}$ BOA.BEO. D: 4326, G: 324414.

${ }^{32}$ BOA.BEO. D: 4471, G: 335325; "Mehmed V", Türkiye Diyanet Vakfi İslam Ansiklopedisi, c.28, s. 61-62.

${ }^{33}$ BOA.BEO. D: 4346, G: 325916; BOA.İ.MBH. D: 17, G: 60; https://en.wikipedia.org/wiki/Robert,_Archduke_of_Austria-Este (26 .11.2015)

${ }^{34}$ BOA.BEO. D: 4350, G: 326224.

${ }^{35}$ BOA.BEO. D: 4365, G: 327333; BOA.İ.MBH. D: 18, G: 16.
} 
tarafından Hariciye Nezaretine ulaştırılmıştır. Bu mektup ve gönderilecek cevabi mektubun müsveddesi Sadaretçe Padişah'a arz edilmiş ve tasvib edildikten sonra tebyiz edilerek İmparatora ulaştırılmak üzere 8 Ağustos 1916 tarihinde Avusturya Sefaretine yazılmıştır ${ }^{36}$.

İmparator Fransuva Jozef'in cenaze merasimine katılmak üzere 22-24 Kasım 1916 tarihlerinde Avusturya'ya giden Veliaht Vahideddin Efendi'nin bu ziyareti sirasında mihmandarlığını yapan General Otto Mare von Madele Lençebrog'a "Birinci Rütbe'den Mecîdî" ve Yüzbaşı Mösyö Hans Körteler'e "Dördüncü Rütbe'den Osmânî" nişanları verilmiştir (10 Ocak 1917) ${ }^{37}$.

Arşidük Maksimilyan ziyareti sırasında İmparator Fransuva Jozef'in vefatı ve kendisini tahta çıktığına dair İmparator I. Fransuva Şarl'ın mektuplarını ve İmparator'un Padişah'a hediye ettiği "Murassa' Harb" ve "Birinci Sınıf Meziyet-i Askeriye" Nişanlarını da Padişah'a takdim etmiştir. Padişah'ın bu mektup ve nişanlara cevaben hazırlanan teşekkür mektubu İmparator'a ulaştırılmak üzere Hariciye Nazırı Ahmed Nesimi Bey'e verilmiştir (22 Şubat 1917) ${ }^{38}$.

Avusturya İmparatoru ve Macaristan Kralı Fransuva Jozef'in vefatı ve I. Şarl'ın tahta çıkışını tebliğ etmek üzere Şubat 1917'de İstanbul'u ziyaret etmiş olan Arşidük Maksimilyan ve beraberindekilerden bazılarına Padişah V.Mehmed Reşad tarafindan nişan verilmiştir. Arşidük Maksimilyan "Murassa' Mecîdî", heyette yer alan Macar Hassa Kumandanı Süvari Generali Kont Lonya "Birinci Rütbeden Osmânî", Sefaret Müsteşarı Kont Konstantin Deim ve Arşidük'ün Teşrifatçısı Kont Fransuva Şesi'ye "İkinci Rütbeden Osmân̂̂", Saray Müdürü ve İmparatorluk Sarayı Mabeyincilerinden Kont Konsolati ile İmparatorluk Sarayı Doktorlarından Kaymakam Mösyö Bilka'ya "Üçüncü Rütbeden Osmânî", saray veznedarlarından Mösyö Hogokerzan ile Arşidük'ün Teşrifat Kâtibi Doktor Leopold Vran'a "Dördüncü Rütbeden Osmânî" nişanları, Arşidük'ün hademelerinden Hilneni Jozef, Kalimar Eymond, Millih, Taki Andrenasi, Bayeral Anton, Karames Varçal, Ştagler, Aynzidler Jozef, Mak Haynzih, Karl Ulman, Dominik Leopold ile Avusturya'nın İstanbul Sefareti Kapıcısı Mehmed Dekiç'e "Gümüş İftihar" madalyaları ile taltif edilmişlerdir (15 Şubat 1332/28 Şubat 1917) ${ }^{39}$.

Avusturya-Macaristan İmparatorluğu veliahdı Arşidük Maksimilyan'in İstanbul'u ziyareti sırasında gösterilen ilgi ve dostluğa bir teşekkür mahiyetinde İmparator tarafından

\footnotetext{
${ }^{36}$ BOA.İ.DUİT. D: 1, G: 73; BOA.BEO. D: 4425, G: 331844; https://en.wikipedia.org/wiki/Charles_I_of_Austria( 9.10.2015)

${ }^{37}$ BOA.İ.DUIT. D: 69 , G: 98

${ }^{38}$ BOA.İ.DUIT. D: 1, G: 71; BOA.MV. D: 246, G: 121.

${ }^{39}$ BOA.İ.DUIT. D: 69, G: 111.
} 
Şehzade Ömer Hilmi Efendi ve Mabeyn-i Hümayun yetkililerinden on kişiye nişan verilmesi kararlaştırılmıştır. Bununla ilgili hazırlanan nişan ve beratları İstanbul'daki Avusturya Sefareti tarafından Hariciye Nezaretine ulaştırılmıştır. Hariciye Nazırı Ahmed Nesimi imzasıyla Sadaret'e gönderilen yazıda; şehzade haricindekilere verilecek nişanlara dair İzahnamelerin ilgililere imza karşıllı̆ı teslim edilmesine müsaade talep edilmiştir. Saray Başkitabeti'nden 11 Nisan 1917 tarihinde verilen cevapta bu talebin uygun bulunduğu bildirilmiştir ${ }^{40}$.

Birinci Dünya Savaşı sırasında uzun süre Hariciye Nazırlığı görevinde bulunan Halil (Menteşe) Bey'e iki ülke arasındaki ilişkilerdeki rolü nedeniyle Avusturya İmparatoru ve Macaristan Kralı I. Şarl Fransuva tarafindan "Büyük Kordonlu Leopold Nişanı" verilmiştir. O dönemde Adliye Nazırlığı ve Şura-yı Devlet Reisliği görevine atanmış olan Halil Bey'in bu nişanı kabulüyle ilgili irade-i seniyye 24 Nisan 1917 tarihinde yayınlanmıştır ${ }^{41}$.

Avusturya İmparatoru, Padişah V.Mehmed Reşad'ın tahta çıkış yıldönümü dolayısıyla Viyana'daki Osmanlı Sefarethanesi Heyetine Laksenburg Kasrı'nda bir ziyafet vermiştir. Yemek esnasında İmparator, Padişahın özelliklerinden ve kendisinin Padişaha karşı beslediği iyi duyguları ifade eden bir konuşma yapmıştır. Bu törenlerle ilgili bilgi verilen ve Hariciye Nezaretinden Sadaret'e sunulan 21 Mayıs 1917 tarihli arizada; İmparator'un taç giymesinin yıl dönümü olan 17 Ağustos'ta Avusturya-Macaristan'ın İstanbul Sefarethanesi Heyeti'ne Sarayda bir ziyafet tertiplenmesine dair Viyana Sefiri Hüseyin Hilmi Paşa'nın hatırlatmasına da yer verilmiştir. Avusturya İmparatoru ile Almanya İmparatoru arasında yıllardır devam eden bir gelenek olarak önemli günlerde İmparatorların bu tür ziyafetler tertip ettiklerine değinilen yazının ekinde 26 Nisan akşamı düzenlenen ziyafete katılan Avusturya-Macaristan yönetimi ve Osmanlı Elçilik Heyeti'ne dair 30 kişilik bir liste sunulmuştur. Sadaretten bu mealde Saraya 26 Mayıs 1917 tarihinde bir ariza takdim edilmiştir. Ser-Kâtib-i Hazreti Şehriyarî Ali Fuad imzasıyla 28 Mayıs'ta verilen cevapta Hüseyin Hilmi Paşa'nın bu önerisinin uygun bulunduğu ve 17 Ağustos'ta Saray'da bir ziyafet tertip edilmesi için gereken tebliğin yapılması istenilmiştir ${ }^{42}$.

\footnotetext{
${ }^{40}$ BOA.İ.DUIT. D: 72, G: 24. Avusturya İmparatoru ve Macaristan Kralı tarafindan nişan verilenlere dair listede şu isimler yer almaktadır: Devletlu necabetlü Ömer Hilmi Efendi Hazretleri (Leopol Nişanı'nın Büyük Kuronu), Seryaver-i Hazret-i Şehriyarî Salih Paşa (Liyakat-i Askeriye Nişanı'nın İkinci Rütbesi), İstabl-1 Âmire Müdiri Kaymakam Şeref Beyefendi, Levazım Memuru Ali Bey (Fransuva Jozef Nişanının Şövalye Rütbesi), Levazım Memur Muavini Aziz Bey (Taçı Altın Liyakat Nişanı), Matbah-1 Âmire Müdiri İsmail Efendi, Yıldız Saray-1 Hümayunu Bekçibaşısı Hacı Şaban Efendi (Altun Liyakat Nişanı), Levazım Memuru Akif Efendi (Taçlı Gümüş Liyakat Nişanı), İstabl-1 Âmireye Mensub Halid Efendi ve Serhademe Abdullah Ağa (Gümüş Liyakat Nişanı).

${ }^{41}$ BOA.İ.DUİT. D: 7, G: 65.

${ }^{42}$ BOA.İ.DUIT. D: $15, \mathrm{G}: 73$.
} 
Avusturya İmparatoru ve Macaristan Kralı I. Şarl Fransuva tarafindan Veliaht Vahideddin Efendi'ye Birinci Rütbeden "Saint Etien", Şehzade Abdülmecid Efendi'ye İkinci Rütbeden Meziyet-i Askeriye, Sadrazam Mehmed Talat Paşa'ya Üçüncü Rütbeden Meziyet-i Askeriye Nişanları verilmiştir (25 Haziran 1917, 31 Temmuz 1917) ${ }^{43}$.

Avusturya-Macaristan tahtına geçmiş olan I. Fransuva Şarl Padişah'a nişan vermişti. Buna bir cevap olmak üzere Padişah tarafından Avusturya İmparatoru ve Macaristan Kralı I.Şarl'a nişan hediye etmiştir. Bu nişanları takdim etmek üzere Şehzade Osman Fuad Efendi, Seryaver Salih Paşa ve Avusturya nezdindeki askeri temsilci Pertev Paşa'dan oluşan bir heyet gönderilmiştir (24 Ekim 1917) ${ }^{44}$.

İmparator I.Şarl'ın 10 Mart 1918 tarihinde dünyaya gelen oğlu Arşidük Carl Ludwig'in doğum haberini içeren mektubu İstanbul'daki Avusturya Sefareti tarafından Osmanlı Hariciye Nezaretine bildirilmiştir. Nezaret de bu mektup 28 Nisan 1918 tarihinde Sadaret'e göndermiştir. Hem bu mektup ve hem de verilecek cevabın müsveddesi Padişah'a arz edilmiştir. Padişah tarafından da uygun bulunan mektubun müsveddesi Sadaret'e iade edilmiştir. Tebyiz edilen mektubun bir nüshası Hariciye Nezareti aracılığıyla İmparator'a ulaştırılmak üzere Avusturya Sefaretine gönderilmiş ve aslı Mabeyn-i Hümayun Başkitabeti'ne sunulmuştur (4 Mayıs 1918) ${ }^{45}$.

Avusturya İmparatoru ve Macaristan Kralı I. Şarl'ın kardeşi Arşidük Maksimilyan ile Prenses Fransuez dö Hohenlohe Şülingfürst'ün (Hohenlohe-Schülingsfürst) evliliklerinin İmparator tarafından bildirilmesi üzerine iyi dilekleri içeren bir cevap hazırlanmıştır. Sadaretçe hazırlanan müsvedde Saraya takdim edilmiş (13 Mayıs 1918) ve uygun bulunan müsvedde metnin beyaza çekilerek İmparator'a yazılması cevabı verilmiştir. Sadrazam Talat (Paşa) imzasıyla Saray'a gönderilen hususi arizada Cevab-name-i Hümayun'un yazıldığı bildirilmiştir (16 May1s 1918) ${ }^{46}$.

\footnotetext{
${ }^{43}$ BOA.İ.DUİT. D: $1, \mathrm{G}: 102$.

${ }^{44}$ BOA.MV. D: 209, G: 88; BOA.MV. D: 258, G: 61; BOA.MV. D: 248, G: 37; BOA.İ.DUİT. D: 1, G: 69. Heyetin masrafları için Masarıf-1 Gayr-i Melhuze ödeneğinden Osman Fuad Efendi'ye 1.500, Salih Paşa'ya 300 harcırah verilmiştir.

${ }^{45}$ https://en.wikipedia.org/wiki/Archduke_Carl_Ludwig_of_Austria_(1918\%E2\%80\%932007); BOA.İ.DUIT. D:1, G: 68. Arşidük Carl Ludwig'in doğumunu tebrik için Padişah tarafindan İmparatora gönderilen Cevab-namede şu ifadeler yer almaktadır: "Bir mahdum-1 muhteremleri zînet-efzâ-yı mihr-i vücud olduğunu müş'ir seviy-yi muhibbânemize irsal k1lınan name-i meveddet-allâme-i İmparatorîleri resîde-i dest-i memnuniyet oldu. Zât-1 Hasmet-simât-1 Hükümdârîlerine derkâr olan müvâlât-1 samimiyemiz iktizâsınca Hanedan-1 Fahamet-Nișan-1 Hükümrânilerine taalluk eden kâffe-i âsâr-1 sâreden hisse-mend olduğumuz cihetle bu keyfiyet dahî bâdî-i ibtihâc olduğundan beyân-1 mahzûziyete ve müşarunileyhin velâdetini tehni'etle beraber te'yîd-i revâbit-1 hubb-ü mesâfâta mübaderet k1lındı. Âsâr-1 muhâdenet-şi'âr-1 Haşmet-penâhîlerinin devamı mültemes-i hâlisânemizdir."

${ }^{46}$ BOA.İ.DUIT. D: 1, G: 67. İzdivacı tebrik için yazılan Cevab-name-i Hümayun metni şu şekildedir: "Birader-i Muhteremleri Fahâmetlü Arşidük Maksimilyan ile Fahâmetlü Prenses Fransuvaz dö Hohenlohe Şülingsfürst
} 
I. Dünya Savaşı'nın sonlarına doğru iki ülke arasındaki ilişkiler sıcaklığını korumaya devam etmekteydi. Bu çerçevede 21 Kasım 1916'da tahta çıkmış olan ve Mayıs 1918'te İstanbul'u ziyaret etmiş olan Avusturya İmparatoru ve Macaristan Kralı I. Şarl (Karl)'a "Murassa' İmtiyaz" ve İmparatoriçe/Kraliçe Zita'ya da kadınlara mahsus "Murassa' Mecidi" nişanı 25 Mayıs 1918 tarihli irade-i seniyye ile verilmiştir. Aynı zamanda 20 Mayıs 1918 tarihli bir başka irade-i seniyye ile de İmparator I. Şarl'a "Müşirlik" payesi verilmiştir ${ }^{47}$.

$\mathrm{Bu}$ geziden kısa bir süre sonra Avusturya İmparatoru ve Macaristan Kralı I.Şarl Sadrazam M. Talat Paşa, Harbiye Nazırı Enver ve Bahriye Nazırı Cemal Paşa başta olmak üzere Osmanlı Hükümeti'nde görev alan kişilere değişik rütbelerde nişanlar vermiş ve 29 Haziran 1918 tarihli irade-i seniyye ile bu nişanların kabulü tasdik edilmiştir ${ }^{48}$.

Sultan V. Mehmed Reşad'ın 3 Temmuz 1918 tarihinde vefatı ile tahta kardeşi VI. Mehmed Vahideddin geçmiş ${ }^{49} 4$ Temmuz'da da biat töreni icra edilmiştir. Uluslararası ilişkilerdeki geleneğe uygun olarak bu taht değişikliğini tebliğ etmek üzere bir heyetin üç müttefik ülke (Almanya, Avusturya-Macaristan ve Bulgaristan) başkentlerine gönderilmesi kararlaştırılmıştır. Sadaret'ten 18 Ağustos 1918 tarihinde Saray Mabeyn-i Hümayun Başkitabeti'ne yazılan bir hususi tezkere ekinde, heyete tevdi edilecek Name-i Hümayun müsveddesi sunulmuştur. Başkitabet'ten bir gün sonra verilen cevapta gönderilmesi uygun bulunan Name-i Hümayun tebyiz edilerek imza için tekrar Saray'a takdim edilmiştir (20 Ağustos 1918). Tasdik ve imza işlemi tamamlandıktan sonra Sadaret'e iade edilen üç Name-i Hümayun; Almanya ve Avusturya-Macaristan İmparatorları ile Bulgar Kralı'na Şehzade Abdurrahim Efendi başkanlığında Vezir Tevfik Paşa ve Binbaşı İsmail Hakkı Bey'den oluşan

Hazretlerinin resm-i izdivaclarının icra kılındığını hâvî irsâl-i savb-1 hâlisânemiz kılınan nâme-i meveddetallâme-i hükümdârîleri resîde-i dest-i memnuniyet oldu. Zât-1 Haşmet-simât-1 İmparatorîlerine derkâr olan muhâdenet-i samimiyetimiz iktizasınca Hanedân-1 bülend-unvanlarına müteallık vukuat-1 sâreden hisse-mend-i ibtihâc (sevinç) olduğumuz gibi bu keyfiyet dahî bâdî-i sürûr-1 bî-şumar (sayısız) olmağla müşarunileyhimânın tehniyet-i (evliliği tebrik) izdivâclarına ibtidâr eylediğimin beyanı te'yid-i revâtıb-1 mühâlesata (dostluk, samimiyet) vesîle-i cemîle ittihaz kılınmış ve daima tezâyüd-i şan-1 haşmet-unvan-1 Hükümrânîleri temennî kılınmakta bulunmuş idüği ma'lum-1 Hükümrânîleri oldukta ba'de-zîn dahî ifa-yı lâzime-i vedâd-kârîye masrûfiyet-i himmet-i İmparatorîleri mültemes-i meccânemizdir."

${ }^{47}$ BOA.İ.DUIT. D: 16, G: 2.

${ }^{48}$ BOA.İ.DUITT. D: 7, G: 82. I.Şarl tarafindan Osmanlı Hükümeti üyelerine verilen nişanlar şunlardır: Mehmed Talat Paşa (Büyük Kordonlu Murassa' Saint Etien), Harbiye Nazırı Enver Paşa (Büyük Kordonlu Saint Etien), Hariciye Nazırı Ahmed Nesimi Bey (Büyük Kordonlu Leopold), Nafia Nazırı Ali Münif Bey, Ticaret ve Ziraat Nazırı Mustafa Şeref Bey, Posta Telgraf ve Telefon Nazırır Hüseyin Haşim Bey (Birinci Rütbeden Leopold), Bahriye Nazırı Cemal Paşa, Adliye Nazırı ve Şura-yı Devlet Reisi Halil Bey ve Maliye Nazırı Cavid Bey (Muharebeye Mahsus Birinci Rütbeden Merit Sivil).

${ }^{49}$ BOA.İ.DUİT. D: 1, G: 49. 
bir Fevkalade Sefaret Heyeti ile gönderilmiştir ${ }^{50}$. Padişah değişikliğinden sonra da Hüseyin Hilmi Paşa'nın Viyana Sefirliği görevine devam etmesi kararlaştırılmıştır (5 Eylül 1918) ${ }^{51}$.

Osmanlı Devleti'ndeki taht değişikliğinden sonra Avusturya İmparatoru ve Macaristan Kralı Fransuva Şarl, yeni Padişah Vahdeddin'e murassa çerçeveli ve şehzadeler İbrahim ve Ömer Hilmi Efendilere çerçeveli kendi resminin bulunduğu tablo hediye etmiştir (24 Ağustos $1918)^{52}$.

İki hanedan arasındaki hediye takdimleri arasında hanedan üyelerinin kendi eserlerini takdim ettikleri görülmektedir. Örneğin; Arşidük Hanry Ferdinand tarafindan kaleme alınan "Merkezi Avrupa Turuk-1 Miyâhîsi (Orta Avrupa Akarsu Yolları)" isimli eserin bir nüshası İstanbul'daki Avusturya Sefiri tarafindan Padişah'a takdim edilmek üzere Hariciye Nezaretine teslim edilmiştir. Hariciye Nezareti bu eseri Sadaret'e göndermiş ve Sadrazam da bir ariza-i hususiye ekinde Saray'a takdim etmiştir. Serkâtib-i Hazret-i Şehriyarî Ali Fuad imzasıyla verilen cevapta; eserin takdimi dolayısıyla Padişah'ın memnun olduğu ve Arşidük Ferdinand'a teşekkür ve iyi dileklerinin iletilmesini irade buyurduğu ifade edilmiştir. Takdim edilen kitap Nafia Nezaretine gönderilmiştir (25-26 Nisan 1917) ${ }^{53}$.

Avusturya Hanedanından Prenses dö Lihtenstayn (Arşidüşes Elisabeth Amalie de Liehtenstein) 1917 yılında İstanbul'u ziyaret etmiş ve "Helden Verk" isimli eserinin birinci cildini Padişah'a takdim etmiştir. Padişah'ın elyazısı örneklerinin de yer aldığı eserin ikinci cildi İstanbul'daki Avusturya Sefareti aracılığıyla Padişah'a takdim edilmiştir. Buna karşıllk

\footnotetext{
${ }^{50}$ BOA.İ.DUİT. D: 1, G: 100; Yusuf Hikmet Bayur, Türk İnk1lâbı Tarihi, C. III/Kısım: IV, s.348-349; Ali Fuad Türkgeldi, age, s. 149. Makalenin konusu gereği bir örnek olması için Avusturya İmparatoru ve Macaristan Kralı'na gönderilen Name-i Hümayun'un metnini vermekte fayda vardır. Metin şu şekildedir: "Birader-i muhabbet-eserim Sultan Mehmed Hân-1 Hâmis Hazretlerinin vukû-1 irtihâliyle ecdâdımızdan mevrûs Taht-1 Osmânîye cülusumuz vukû' bulduğunu Zât-1 Haşmet-simât-1 Hükümdârîlerine tebliğ eylemek üzere Şehzade Abdurrahim Efendi'nin riyasetinde Efâhim-i Vüzerâmızdan olup Murassa' İmtiyâz ve Mecîdî ve Osmânî Nişanlarını hâmil Tevfik Paşa ile Damadımız İkinci Rütbe Osmânî Nişanını hâmil Ordû-yı Hümâyûnumuz Binbaşılarından İsmail Hakkı Bey'den mürekkeb bir Hey'et-i Fevkalâde-i Sefareti cânib-i muhâlasat-câlib-i haşmetânelerine i'zam ile kesb-i fahr eylerim. Ehass-1 mesâ'î ve âmâlim Devlet-i Aliyyemizle Devlet-i Fehîmeleri beyninde teyemmünen cârî olan münâsebât-1 ittifâkiye ve revâbit-1 dûstânenin bir kat daha takviyesine ve Zât-1 Haşmet-penâhîlerine derkâr olan meveddet-i hâlise ve hürmet-i fâikamın te'yîdine masrûf olacağından Zât-1 Âlî-i Hükümdârîlerinin dahî aynı hissiyât mütehassis olduklarına ve Devlet-i Aliyyemiz hakkında ba'dezîn dahî âsâr-1 dûstî ve muhâdenet ibrâz buyuracaklarına emniyetimiz ber-kemâl olduğunu beyan ve eyyâm-1 ömr ve âfiyet-i Haşmet-penâhîlerinin temâdîsi ve memâlik-i aliyye-i İmparatorîlerinin tezâyüd-i sa'âdeti ed'iye-i hâlisânesini bu zerî'a (vesile) ile de tekrâr eylerim."

Heyetin masrafları için Masarıf-1 Gayr-i Melhuze ödeneğinden Abdurrahim Efendi'ye 1.500, Tevfik Paşa'ya 1.000 ve İsmail Hakkı Bey'e 750 lira harcırah verilmiş̧ir. Bk: BOA.MV. D: 212, G: 137.

${ }^{51}$ BOA.İ.DUIT. D: 1 , G: 66.

52 BOA.İ.DUİT. D: 1, G: 50.

${ }^{53}$ BOA.İ.DUIT. D: 17, G: 12; BOA.BEO. D: 4466, G: 334950.
} 
Padişah'ın teşekkür ve memnuniyetini ifade eden bir mektubu aynı şekilde Sefaret'e ulaştırılmıştır (17 Haziran 1918) $)^{54}$.

\section{3- Taziyeler}

İki hanedan arasındaki dostane ilişkiler yaşanan vefatlar sebebiyle de izhar edilmiş ve üzüntüler paylaşılmıştır. I. Dünya Savaşı'nın da kıvılcımı olan Arşidük Fransuva Ferdinand d'Est ve Eşi Prenses Sofia'nın suikastle öldürülmesinden dolayı Padişah adına Avusturya İmparatoru ve Macaristan Kralı I. Fransuva Jozef'e bir taziye mektubu gönderilmiştir (14 Eylül 1914). Bu mektubun metni şöyledir ${ }^{55}$ : "Fahametlû Arşidük Fransuva Ferdinand d'Est Hazretleriyle zevce-i muhteremeleri Fahametlû Arşidüşes de Hohenburg Hazretlerinin hâinane bir suikast neticesinde vefat eylediklerini müş'ir irsâl-i seviyy-i muhibbânemiz kılınan nâme-i İmparatorîleri resîde-i hâlisânemiz oldu. Âlem-i insaniyeti dâğıdâr-1 teessüf eden bu cinayet-i le'îmânenin (alçakça) zât-1 Âlî-i Hükümrânîlerince hasıl eylediği te'essürâta hasbe'l-ihlâs bütün kalbimle iştirâk ederek mürettip ve mütecâsirlerini en amîk (derin) bir hiss-i nefrîn (lanet okuma) ile yâd ve zât-1 mekârim-sıfât-1 hükümdârîlerinin bi'l-cümle azâ-y1 hanedan-1 zîşanlarının savt-1 Samedânîde mahzûziyet ve temâdî-i ömr-ü âfiyetleri de'avâtını (dualarını) irâd ile îfâ-yı lâzime-i ta'ziyet ve beyân-1 hüzn-ü küdûrata ve cânib-i haşmet-câlib-i İmparatorîlerine derkâr olan ihtirâmât-1 fâ'ikamızın temdîd-i te'mînâtına ibtidâr ederim."

Bu üzücü olay dolayısıyla Avusturya'nın Osmanlı topraklarındaki resmi kuruluşlarının ve vatandaşlarının bayrakları yarıya indirmelerine engel olunmadığı gibi sürekli bayrak asılan Osmanlı resmi binalarında da bayraklar yarıya indirilmiştir ${ }^{56}$.

Yine bu dönemde vefat eden Arşidüşes Adelgunde Doeryer'in vefatı dolayısıyla İmparator I. Fransuva Jozef'e bir taziye mektubu göndermiştir (29 Aralık 1914) ${ }^{57}$.

Avusturya İmparatoru ve Macaristan Kralı Fransuva Jozef'in akrabası Arşidük Renier'in eşi Prenses Marie'nin 17 Temmuz 1915'te ölümü üzerine İmparator'a bir taziye mektubu göndermiştir (26 Eylül 1915) ${ }^{58}$.

\footnotetext{
${ }^{54}$ BOA.İ.DUIT. D: 1 , G: 61.

${ }^{55}$ BOA.BEO. D: 4310, G: 323212; BOA.MV. D: 236, G: 84; BOA.İ.MBH. D: 16, G: 56.

${ }^{56}$ BOA.DH.EUM.EMN., D: 87, G: 53.

${ }^{57}$ BOA.BEO. D: 4328, G: 324593; BOA.İ.MBH. D: 17, G: 20.

${ }^{58}$ BOA.İ.MBH. D: 18, G: 57. Mektup yaklaşık iki ay sonra gönderilmiştir. Ancak o dönem şartlarında bu süre pek de anormal gözükmüyor. Çünkü İmparator'un Prensesin vefat haberini içeren mektubu 18 Ağustos 1916 tarihlidir. $B k$ : Aynı dosya.
} 
İmparator'un kayınbiraderi Arşidük Lui Sudur'un vefatı dolayısıyla da Padişah adına İmparator'a bir taziye mektubu gönderilmiştir (14 Aralık 1915) ${ }^{59}$.

İmparator Fransuva Jozef 21 Kasım 1916'da vefat etmiştir. Bunun öğrenilmesinden sonra bir heyet Avusturya'nın İstanbul Sefaretine gönderilmiş ve Padişah'ın taziye dilekleri iletilmiştir. Ayrıca Sefarethane'de düzenlenen dini törende Şehzade Ziyaeddin Efendi başkanlığında bir heyet de hazır bulunmuştur. Bu yakın ilgi dolayısıyla Avusturya Sefiri Pallavicini, Padişah'ı ziyaret ederek teşekkürlerini ifade etmiştir ${ }^{60}$.

İmparator Fransuva Jozef'in cenaze törenine katılmak üzere bir heyet gönderilmesi kararlaştırılmıştır. Heyet-i Vükelâ'ca Osmanlı Devleti'ni temsilen Veliaht Vahideddin Efendi başkanlığında, Serkarîn-i Esbak Lütfi Bey, Seryaver Salih Paşa, Vahideddin Efendi'nin Teşrifatçısı Salih İhsan ve Teşrifat Müdür Muavini Fuad Beylerden mürekkep bir heyet oluşturulmuştur. Buna dair irade-i seniyye 13 Teşrinisani 1332 (26 Kasım 1916) tarihinde tasdik edilmiştir. Ayrıca Padişah adına anıt mezara bir çelenk konulması kararlaştırılmıştır ${ }^{61}$.

1912 yılında Başmabeyincilik görevinden kendi isteği ile ayrılan Lütfi Simavî Bey'in bu heyette yer alması ilginçtir. Sadrazam Said Halim Paşa'nın isteğiyle bu heyette yer alan Lütfi Simavî Bey bu ziyaret hakkında ayrıntılı bilgiler vermektedir. 22 Kasım 1916 Çarşamba günü saat 10'da İstasyonunda başlayan seyahat esnasında Karaağaç İstasyonu'nda Bulgar Mutasarrıfı ve Niş'te bir Alman askeri birliği tarafından selamlanmıştır. 23 Kasım 1916 tarihinde Viyana'ya varıldığında başta yeni İmparator I.Şarl olmak üzere Avusturyalı yetkililer ve Osmanlı Sefareti görevlileri tarafindan karşılama töreni yapılmıştır. Heyetlerin karşılıklı takdiminden sonra otomobillerle Hofburg Sarayı'na geçilmiştir. Burada Veliaht Vahideddin Efendi ve heyette bulunanlar İmparatoriçe'ye takdim edildikten sonra başsağlığ 1 temennisinde bulunulmuştur. Daha sonra Sarayda Vahideddin Efendi'nin ikameti için ayrılan daireye geçilmiş ve yemekten sonra veliaht ve Lütfi Simavî Bey burada kalırken heyetteki diğer kişiler Otel Emperyal'e intikal etmişlerdir. 23 Kasım 1916 Perşembe günü Aleksandra Dairesindeki resmikabul törenine katılan Veliaht Vahideddin Efendi kabul için beklenildiği esnada Vahideddin Efendi İsveç Veliahtı ve İspanya prensi ile tanışmıştır. Daha sonra İmparator ve İmparatoriçe tarafından kabul edilen Vahideddin Efendi, İmparator ve İmparatoriçe'ye Padişah adına hem taziyede

${ }^{59}$ BOA.İ.MBH. D: 19, G: 18.

${ }^{60}$ BOA.İ.DUIT. D: $16, \mathrm{G}: 46$.

${ }^{61}$ BOA.MV. D: 204, G: 18; BOA.İ.DUİT. D: 1, G: 72; BOA.MV. D: 204, G: 87; BOA.MV. D: 207, G: 24; BOA.MV. D: 246, G: 22; BOA.BEO. D: 4459, G: 334410. Heyettekiler için verilen harcırah miktarları şu şekildedir: Veliaht Vahideddin Efendi'ye 2000, Lütfi Bey ve Salih Paşa'ya 200, Salih İhsan ve Fuad Beyler ile iki yavere 100 lira, çelenk için 3055 kuruş. 
bulunmuş ve hem de tebrik etmiştir. Kabul esnasında iki müttefik ülke için savaşın gidişatı ile ilgili olarak temennilerde bulunulmuş ve gelecek için dostluk ifadeleri dile getirilmiştir ${ }^{62}$.

İmparator Fransuva Jozef'in cenazesi önce Saint Etienne Kilisesindeki dini törenin ardından Habsburg Hanedanının üyelerinin çoğunun kabirlerinin bulunduğu Capucin Kilisesi'ne gömülmüştür. Törenden sonra Hofburg Sarayı'na dönen Vahideddin Efendi, burada Rusya Cephesi Başkumandan'1 ve İmparator Fransuva Jozef'in damadı olan Leopold de Bavyer'i kabul etmiştir. $\mathrm{Bu}$ görüşme esnasında Başkumandan, kendi emrine verilmiş olan Osmanlı Kolordu'sunun kahramanlıklarını dile getirmiş ve bundan dolayı Veliaht'a tebriklerini iletmiştir. Daha sonra Osmanlı Sefarethanesine gidilmiş ve Hofbur Sarayı'na dönüşte İmparator ve İmparatoriçe Vahideddin Efendi'ye iade-i ziyarete gelmişlerdir. Ertesi günü (24 Kasım 1916) Veliaht Efendi Saray'dan Sefarethane'ye nakl-i ikamet etmiş ve daha sonra Sefarethane yetkilileri, Avusturya'daki Hilal-i Ahmer temsilcileri ile birlikte Viyana'da tedavi edilmekte olan Osmanlı askerlerini ziyaret etmişlerdir. Akşam yemeği Sefarethane'de yenildikten sonra gece saat 23 'te özel trenle Budapeşte'ye hareket edilmiş ve buradaki hastanelerde tedavi gören askerlerimiz ziyaret edilmiştir. Otel Ritz'de yenen öğle yemeğinden sonra kısa bir şehir gezintisi yapılmış ve saat 15 'te İstanbul'a hareket edilmiştir. Semlin şehrinde Avusturya topraklarından çıkılırken İmparatora hitaben iyi dilek ve şükran ifadelerini içeren bir telgraf çekilmiştir. Sofya İstasyonu'nda Bulgar Hükümeti yetkilileri ve Türk Sefareti yetkililerinde selamlanan Veliah Vahideddin Efendi daha sonra İstanbul'a dönmüştür. İstasyonunda törenle karşılanan Vahideddin Efendi'ye Avusturya'nın İstanbul Sefiri İmparatorun cevabi telgrafının takdim etmiştir ${ }^{63}$.

Veliaht Yusuf İzzeddin Efendi'nin 1 Şubat 1916 tarihinde meydana gelen beklenmeyen ve şüpheli ölümü yurt içinde ve dışında yankı bulmuştur. Bu üzücü olay nedeniyle diğer devlet yetkililerince olduğu gibi Avusturya-Macaristan yöneticileri tarafindan taziye mesajları gönderilmiş ve ziyaretlerde bulunulmuştur. İstanbul'daki Avusturya Sefiri Hariciye Nezaretine gelerek Viyana'daki Avusturya Kabinesi, Avusturya-Macaristan Hükümeti adına taziyelerini bildirmiştir. Ayrıca Dış işleri Bakanı, Hükümet üyeleri ve Avusturya önde gelenleri Viyana'daki Osmanlı Sefarethanesine gelip taziyelerini iletmişlerdir. Mabeyn-i Hümayun Başkitabeti'nden Sadaret'e yazılan 26 Kanunusani 1331 (8 Şubat 1916) tarihli yazıda "Avusturya cânibinden bu vesile dahî izhâr edilen âsâr-1 muhâlâsat-şi'arı ayrıca müstelzim-i hoşnûdî-i Hümayun olmuş"

\footnotetext{
${ }^{62}$ Lütfi Simavi, Osmanlı Sarayının Son Günleri, Hürriyet Yay., İstanbul, 1972, s.345-349.

${ }^{63}$ Lütfi Simavi, a.g.e., s. 350-352.
} 
ifadesi, Avusturya-Macaristan yönetiminin ilgi ve ziyaretlerinin Padişah'ta uyandırdığ1 memnuniyeti göstermektedir ${ }^{64}$.

3 Temmuz 1918 tarihinde Padişah V.Mehmed Reşad'ın vefatı üzerine Avusturya İmparatoru ve Macaristan Kralı, Dış işleri Bakanı Kont Buryan'ı Viyana'daki Osmanlı Sefarethnesi'ne göndererek bir merasim yapılıp yapılmayacağını sordurmuştur. Mutat bir merasimin olmadığ1 cevabı üzerine İmparatoriçe ile birlikte Viyana'daki Osmanlı Sefarethanesine gelerek taziyelerini iletmiştir ${ }^{65}$.

Osmanlı tahtında bu değişiklik yaşanırken aynı zamanda İmparatorun doğum günü (17 Ağustos 1887) ${ }^{66}$ yaklaşmaktaydı. İmparator ve İmparatoriçe'nin yukarıda belirtilen ziyaret jestlerine bir karşılık olmak üzere bu doğum gününde fevkalade bir jest yapılması gündeme gelmiştir. Sadaret'ten bu konuyla ilgili olarak 10 Ağustos'ta Saraya gönderilen arizaya 13 Ağustos'ta Başkâtip Ali Fuad imzasıyla verilen cevapta; V.Mehmed Reşad'ın vefatı dolayısıyla yaptığı bu ziyarete atıf yapıldıktan sonra buna bir karşılık ve bir defaya mahsus olmak üzere Veliaht Abdülmecid Efendi başkanlığında bir heyetin 17 Ağustos'ta sabah saat 10'da Yeniköy'deki Avusturya Sefaretine tebrik için gitmesinin kararlaştırıldığı ve bu durumun Abdülmecid Efendi'ye de bildirildiği belirtilmektedir. Ayrıca Padişah tarafından Dolmabahçe Sarayında İmparator şerefine Avusturya-Macaristan Sefareti Heyetine bir öğle ziyafeti verileceği bildirilmektedir ${ }^{67}$. Böylece İmparatorun jestine karşılık olarak bir görevli yerine Veliaht'ın Sefarethane gönderilmesi, iki ülke hanedanları arasındaki ilişkilerin gidişatı hakkında da fikir vermektedir.

\section{4- Yardımlar}

Birinci Dünya Savaşı'nda çeşitli cephelerde birlikte savaşan iki devletin, ordularına destek olma konusunda da birliktelikleri göze çarpmaktadır. Hilâl-i Ahmer Cemiyeti'nin yurtdışında başlattığı yardım kampanyasında Avusturya İmparatoru ve Macaristan Kralı

\footnotetext{
${ }^{64}$ BOA.İ.DUIT. D: 3, G: 61. Yusuf İzzeddin Efendi'nin ölümünden sonra yapılan incelemelere göre Veliaht'in bankalara ve diğer kişilere toplam 9.716.106 kuruş borcu 1.883.495 kuruş parası olduğu anlaşılmıştır. Mevcut para düşüldüğünde kalan borç miktarı; 7.832 .610 kuruş olduğu görülmektedir. Günden güne faizleri artmakta olan borçların varisleri sıkıntıya sokması tehlikesine karşılık bir seferde ve toptan ödenmesi kararlaştırılmışır. Bunun için oluşturulan Komisyon, Veliaht'ın varislerinin Vasisi Hacı Evliya Efendi ile de görüşerek borçların tesviyesi yollarını araştırmışır. Bunun için kredi alınırken bankalara rehin bırakılan mücevherlerin açık arttırma ile satılması ve Veliaht'ın taşradaki emlakinin Hükümet tarafindan değeri üzerinden satın alınması kararlaştırılmıştır. Mücevherler için Avusturyalı bir şirket 50.000 lira teklif etmiştir. Şirketle pazarlık ve emlakin satılması için Hacı Evliya Efendi'ye yetki verilmiștir. BOA.İ.DUİT. D: 3, G: 70.

${ }^{65}$ BOA.İ.DUIT. D: 1 , G: 59.

${ }^{66} \mathrm{https} / / /$ tr.wikipedia.org/wiki/I._Karl (21.12.2015)

${ }^{67}$ BOA.İ.DUIT. D: 15 , G: 75.
} 
Fransuva Jozef 40.000 kron bağışta bulunmuş ve yardımseverliğe bir teşekkür olmak üzere Hilâl-i Ahmer Altın Madalyası takdim edilmiştir (30 Mayıs 1915) ${ }^{68}$.

Hilal-i Ahmer (Kızlay) Cemiyeti'nin Avusturya'daki kampanyalarında Padişah V.Mehmed Reşad'ın resminin de kullanılması gündeme gelmiştir. Hilal-i Ahmer Cemiyeti'nin bu yöndeki başvurusu Meclis-i Vükelâ'ca da uygun bulunduğundan, Avusturya'daki kampanyalarında (broşür, pul, afiş vb.) Padişah'ın resminin kullanılmasına müsaade edildiğine dair irade çıkmıştır. Yurt dışında yardım toplamak amacıyla buna müsaade edildikten sonra Hilal-i Ahmer Cemiyeti, aynı amaçla yurt içinde de Padişah'ın resminin çoğaltılıp satılması ve bu şekilde bağış toplanmasına izin verilmesi için Hükümete başvurmuştur. Meclis-i Vükelâ'da görüşülen ve kabul edilen bu isteğe dair Meclis-i Vükela Kararı Padişah tarafından da tasdik edilmiştir (14 Teşrinievvel 1331/27 Ekim 1915) ${ }^{69}$.

Avusturya'da savaşan askerlerin soğukla mücadelelerine yardım amacıyla kurulan "Soğuğa Karşı Cemiyeti" adına Osmanlı Padişahından yardım talep edilmiştir. Avusturya İmparatoru'nun özel danışmanı olan Viktor Matteh tarafından 21 Şubat 1916 tarihli bir ariza ile Padişahtan bağış talebinde bulunulmuştur. Arizada; askerlerin dul ve yetimlerine yardım için Arşidüşes Zita ve Arşidük Şarl Etyen (Charles Etienne)'in himayesinde kurulan "Kälteschutz" isimli yardım kuruluşunun İmparator I. Fransuva Jozef'in izni ile ölen askerlerin isimlerini yaşatmak amacıyla altından defne yaprak ve dalları motifli ve Sarayın kapısına yerleştirilmek üzere bir anıt yaptıracağı belirtilmektedir. İlk olarak İmparator I. Fransuva Jozef ve Alman İmparatoru II. Wilhelm'in birer dal satın alarak yardım ettikleri kampanyaya iki ülkeden önde gelen kişilerin de bağışta bulundukları kaydedilen arizada, "1914-1916 Harb-i Umumisi Kahramanlarına" isimli bir kitabın da hazırlanacağı kaydedildikten sonra Padişah Hazretlerinin de bir dal satın alarak hediye etmesi istirham edilmektedir. Ayrıca bu anıtın açılışı için bir temsilci davet edilmektedir. Cemiyetin bu arizasının tercümesi Viyana Sefaretince Hariciye Nezaretine gönderilmiş ve 5 Mart 1332 (18 Mart 1916) tarihinde Sadaret'e ulaştırılmıştır. 7 Mart 1332 (20 Mart 1916) tarihinde Sadrazam'ın "hususi arizası" olarak Padişah'a takdim edilen "Soğuğa Karşı" Cemiyetinin talebi Padişah tarafından münasip görülmüştür. Serkâtip Ali Fuad imzası ile 8 Mart 1332 (21 Mart 1916 tarihinde Sadarete gönderilen yazıda; Padişah'ın da iki

\footnotetext{
${ }^{68}$ BOA.İ.A. D: 1, G: 64. Aynı kampanyaya Alman İmparatoru II. Wilhelm 40.000 mark ve Krupp Silah Fabrikas1 sahibi Mösyö Krup da 40.000 mark yardımla katkıda bulunmuşlar ve onlara da Hilâl-i Ahmer Altın Madalyası verilmiştir. Bk: BOA.İ.A. D: 1, G: 64 .

${ }^{69}$ BOA.MV. D: 199, G: 80; BOA.MV. D: 241, G: 180; BOA.İ.MMS. D: 200, G: 35. Benzer bir gelişme de Burdur'da yaşanmış ve Abdîzâde İbrahim Efendi isminde bir tüccar Padişah'ın, Almanya ve Avusturya İmparatorlarının resimlerini içeren bir seccade yapmış ve Padişah'a hediye etmiştir. Bk: BOA.DH.KMS., D: 42, G: 6.
} 
İmparator'un yaptığı bağış miktarı olan 1.000 kron tutarındaki bir bağışta bulunmasının uygun bulunduğu ve bu paranın bir görevli ile Sadaret'e ulaştırılması için Hazine-i Hassa-i Şahane Müdiriyeti'ne emir verildiği belirtilmektedir. Bağışla ilgili çek, ilgili Hükümet'e iletilmek üzere 25 Mart 1916 tarihinde tezkere ekinde Sadaret'ten Hariciye Nezaretine gönderilmiştir ${ }^{70}$.

I.Dünya Savaşı anısına Viyana'da dikilen abidenin 6 Mart 1915'te yapılacak açılış törenine Padişah'ı temsilen Viyana Sefiri Hüseyin Hilmi Paşa'nın katılması ve bu törende ölen askerlerin dul ve yetimleri için bağış toplandığında, Almanya Sefiri tarafından verilecek miktarda yardım yapılması Hariciye Nezaretine tebliğ edilmiştir (2 Mart 1915) ${ }^{71}$. Hem bu törenler ve hem de bağışların toplanmasındaki rolü dolayısıyla Osmanlı Devleti'nin Viyana Sefir-i Kebiri Hüseyin Hilmi Paşa'ya İmparator Fransuva Jozef tarafından "Salib-i Ahmer" nişanı verilmiştir (14 Mayıs 1916) ${ }^{72}$.

Benzer bir yardım kampanyası Avusturya-Macaristan Ordusu'na mensup subay ve erlerden hayatını kaybedenlerin dul ve yetimleri için düzenlenmiştir. Arşidüşes Mary Valerin öncülüğünde İmparator'un himayesinde başlatılan kampanyaya Avusturya içinden ve dışından bağışlar yapılmış ve belirli bir miktarın üstünde bağış yapanlara İmparatorun heykelleri dağıtılmıştır. Bu kampanyayla ilgili olarak İstanbul'daki Avusturya-Macaristan Sefaretince Hariciye Nezaretine verilen muhtırada kampanya hakkında bilgi verilmekte ve Bulgar Kralı'nın da 2.000 frank yardım yaptığı kaydedildikten sonra Padişah Hazretleri'nin de desteği talep edilmektedir. Hariciye Nazırı Halil Bey imzalı bir yazı ile durum Sadaret'e bildirilmiş ve Sadrazam tarafından konuyla ilgili bir hususi ariza takdim edilmiştir. Serkâtip Ali Fuad Bey imzası ile verilen cevapta; Padişah'ın bu kampanyaya 2.500 frank bağışladığı ve bu paranın ödenmesi için Hazine-i Hassa-i Şahane Müdüriyeti'ne tebligat yapıldığg bildirilmektedir (22 Haziran 1332/5 Temmuz1916) $)^{73}$.

Savaş sırasında iki ülke halkları ve ordularına yardım konusunda Hanedan üyelerinin de teşvik ve himayeleri ile Hilâl-i Ahmer (Kızılay) ve Salîb-i Ahmer (Kızılhaç) Cemiyetleri oldukça önemli roller oynamışlardır. $\mathrm{Bu}$ gayretlerin takdiri anlamında Cemiyet idarecileri madalyalarda ödüllendirilmişlerdir. $\mathrm{Bu}$ cümleden olarak Hilâl-i Ahmer Cemiyeti yöneticilerinden 19 kişiye (21 Şubat 1916) ve Viyana Sefiri Hüseyin Hilmi Paşa'ya Almanya ve Avusturya Hükümetleri tarafından nişan ve madalya verilmiştir. Aynı şekilde Avusturya Salîb-i

\footnotetext{
${ }^{70}$ BOA.İ.DUİT. D: 15, G: 80; BOA.BEO. D: 4405, G: 330309; BOA.BEO. D: 4405, G: 330347.

${ }^{71}$ BOA.BEO. D: 4341, G: 325502; BOA.İ.MBH. D: 17, G: 49.

${ }^{72}$ BOA.BEO. D: 4413 , G: 330938.

${ }^{73}$ BOA.İ.DUIT. D: 15 , G: 82.
} 
Ahmer yöneticilerinden 11 ve Macar Salîb-i Ahmer yöneticilerinden 7 kişiye Gümüş ve Tunç Hilâl-i Ahmer Madalyası verilmiştir (30 Nisan 1916) ${ }^{74}$.

\section{5- Elçi Kabulleri}

Osmanlı Devleti ile Avusturya-Macaristan İmparatorluğu arasındaki iyi ilişkilere verilen önem diplomatik atamalara da yansımıştır. Her iki Hükümet diğeri nezdinde güçlü ve önemli isimleri büyükelçi olarak görevlendirmişlerdir. Osmanlı Devleti'nin Viyana Sefirliği'ni eski sadrazamlardan Hüseyin Hilmi Paşa ve Avusturya-Macaristan'ın İstanbul Sefirliği'ni Marki Pallavicini (Johann Markraf von Pallavicini) yürütmüştür. Hükümet yetkilileri ile sıklıkla yapılan görüşmeler yanında, her iki sefir de defalarca Padişah ve İmparator tarafından kabul edilmişlerdir.

Hüseyin Hilmi Paşa'nın gönderdiği raporlarda iki ülke arasındaki ilişkilerin düzeyi görülmektedir. Viyana'dan 3 Ocak 1914 tarihinde Hariciye Nezaretine gönderdiği raporda İmparator Hazretlerine itimatnameyi sunduktan sonra Veliaht Fransuva Ferdinand (Archduke Franz Ferdinand d'Est) ile diğer Arşidük ve Arşidüşes'lerle görüşme talep ettiğini belirten H.Hilmi Paşa; Veliaht'la görüşmesinin sonraya bırakıldığını, bunun dışında İkinci Veliaht Şarl Fransuva (Archduke Charles Franz, 1916'da İmparator I. Şarl) ile annesi ve prenseslerle görüşebildiğini anlatmıştır. Veliaht'la görüşememesinin Osmanlı Devleti'ne karşı bir tavır olarak yorumlanmaması gerektiğini vurgulayan H.Hilmi Paşa, Veliaht'ın sağlık durumu nedeniyle sürekli olarak şatosunda ikamet etmesi ve nadiren Viyana'ya gelmesinden dolayı kendisinden 6 ay önce göreve başlayan Fransız elçisinin bile henüz görüşemediğini kaydetmiştir. Yeni yılın başlamasından sonra Yaverlerinden von Der Straten'i Elçiliğe göndererek, o zamana ziyareti kabul edemediğinden dolayı üzüntüsünü bildiren Veliaht; 2 Ocak 1914'te bu ziyaretin gerçekleşebileceğini belirtmiştir. 2 Ocak 1914'te gerçekleşen görüşmede; bir Alman gazetesinde Padişahın sağlığı ile ilgili olarak yayınlanan abartılı haberle ilgili teessürlerini ifade eden Veliaht'ın konu ile ilgili sorularına H.Hilmi Paşa tarafından tatminkâr cevaplar verilmiştir. Daha önce Anadolu ve Suriye'nin bazı yerlerini gezdiğini anlatan Veliaht, İstanbul'u ziyaret etmediğini belirtince; H.Hilmi Paşa böyle bir ziyaretten duyulacak memnuniyeti vurgulamıştır. Balkan Savaşları’yla ilgili konuşmalar esnasında Veliaht, Osmanlı Ordusu'nun gösterdiği çabaları övmüş ve Alman Askerî Islah Heyetinin de yardımıyla bu ordunun daha da güçlenmesi ümidini dile getirmiştir. Görüşmenin sonunda H.Hilmi Paşa'yı

\footnotetext{
${ }^{74}$ BOA.BEO. D: 4457, G: 334252; BOA.İ.DUITT. D: 72, G: 5: BOA.MV. D: 242, G: 60; BOA.MV. D: 246, G: 118.
} 
uğurlarken Paşa'nın taşıdı̆̆ imtiyaz nişanını inceleyen Veliaht babasının da bu nişanı taşıdığından bahsetmiştir. Bu görüşmenin ayrıntılarına dair raporun son kısmında H.Hilmi Paşa, iki ülke arasındaki ilişkilere yapacağı olumlu etki açısından uygun bir zamanda Veliaht'a da İmtiyaz Nişanı'nın verilmesi için kendisinin başvuru yapacağını kaydetmiştir ${ }^{75}$.

1906 y1lından itibaren İstanbul'da Avusturya-Macaristan İmparatorluğu'nun Büyükelçiliği görevini yürüten Marki Pallavicini, Birinci Dünya Savaşı sırasında da bu görevini sürdürmüştür. $\mathrm{Bu}$ çerçevede çeşitli defalar Padişah'ın huzuruna kabul edilmiştir. İzinli olarak ülkesine gitmiş olan M.Pallavicini 1916 yılı Ağustos ayında İstanbul'a geldiğinde huzura kabul için Hariciye Nezaretine başvurmuştur. Sadaret aracılığıyla bu istek Saray'a arz edilmiş ve Mabeyn-i Hümayun Başkitabeti'nden verilen cevapta 8 Ağustos 1332/21 Ağustos 1916 tarihinde saat üçte kabulün gerçekleşeceği bildirilmiştir. Avusturya-Macaristan İmparatorluğu'ndaki taht değişikliğinden sonra yeni İmparator I. Şarl tarafindan M.Pallavicini İstanbul Sefirliği görevine tekrar atanmıştır. İtimatnamesini takdim etmek için Hariciye Nezaretine başvuran M.Pallavicini'n bu isteği Sadaret aracılığıyla Saraya arz edilmiş ve 24 Mart 1917 Salı gününe randevu verilmiştir. Aynı konu ile ilgili olarak M.Pallavicini'ye 12 Mayıs 1917 tarihinde bir randevu daha verilmiştir. İzinli olarak ülkesine giden M.Pallavicini İstanbul'a geldikten sonra İmparator'un selam ve hürmetlerini ve yeni Sefaret Müsteşarı Ştayn'ı takdim etmek amaciyla huzura kabulünü talep etmiş ve 31 Ekim 1917 tarihinde Padişah tarafindan kabul edileceği cevabı verilmiştir. 1918 Mayısında ülkesine gitmek isteyen M.Pallavicini, yola çıkmadan önce Padişah'la görüşmek istemiş ve 30 Mayıs 1918 tarihine randevu verilmiştir. Savaşın sonlarına doğru İmparator tarafından Büyükelçilik unvanı dışında Özel Temsilci olarak atatan M.Pallavicini, randevu talep etmiş ve 24 Ekim 1918 tarihinde Padişah tarafından kabul edileceği cevabı verilmiştir ${ }^{76}$.

\section{Sonuç}

Daha önce çeşitli defalar savaşmış olsalar da, I. Dünya Savaşı döneminde Osmanlı Devleti ile Avusturya ve Macaristan iki ülke arasındaki ilişkilerde dostluk ve bundan öte bir müttefiklik yaşanmıştır. Almanya ile yapılan ittifak benzeri bir anlaşmanın iki ülke arasında da imzalanmasından sonra ilişkiler hızla gelişmeye başlamıştır. Osmanlı Devleti ile Avusturya arasında makalenin ilgili bölümünde bahsedildiği üzere birçok anlaşma imzalanmıştır.

\footnotetext{
75 BOA.HR.SYS. D: 217, G: 69.

${ }^{76}$ BOA.İ.DUIT. D: 16, G: 44; BOA.BEO. D: 4469, G: 335102.
} 
Dış politikada birlikte hareket eden iki devlet, cephelerde de beraber savaşmıştır. Osmanlı cephelerinde Avusturyalı birlikler görev yaparken, Romanya ve Rusya Cephesi'nde de Osmanlı birlikleri savaşmışlardır.

İki ülkeyi yöneten hanedanlar arasında da tebrik, nişan ve hediye takdimi, taziye ve ziyaretler yaşanmış ve böylece dostluk ve dayanışma örnekleri sergilenmiştir. İmparator I. Şarl'ın ve Arşidük Maksimilyan'ın İstanbul'u, Veliaht Mehmed Vahideddin Efendi'nin Viyana'yı ziyaretleri bu dostane ilişkilerin en önemli örnekleridir.

İmparator I. Fransuva Jozef ile Padişah V. Mehmed Reşad'ın vefatları dolayısıyla karşılıklı ziyaret ve gönderilen mektuplarla üzüntüler paylaşılmıştır. Bunun yanında Veliaht Yusuf İzzeddin Efendi ve Habsburg Hanedanından vefat edenler dolayısıyla gönderilen mektuplarla acılara ortak olunmuştur.

I. Şarl ve VI. Mehmed Vahideddin'in tahta çıkışları da karşılıklı ziyaret ve tebriklerin yaşanmasına sebep olmuştur. Ayrıca hanedan üyelerinin çocuklarının doğumu sevinç ve tebrik vesilesi olmuştur.

Savaş sırasında hem ordular ve hem de halkların yaşadığı sıkıntıların hafifletilmesi için iki ülkenin yardım kuruluşları Hilâl-i Ahmer ve Salîb-i Ahmer Cemiyetleri çeşitli kampanyalar düzenlemişlerdir. Bu kampanyalara iki hanedan üyeleri de destek vermişler ve bir bakıma yardımlaşmada yarışmışlardır.

İki hanedan ve iki devlet arasındaki bu dostane ilişkiler, I. Dünya Savaşı'nın kaybedilmesi ile buruk bir havaya bürünmüştür. Her iki ülkede yaşanan gelişmeler sonrasında, her iki hanedan yönetimden uzaklaşmak gibi dramatik bir sonucu yaşamışlardır.

\section{Kaynaklar}

Başbakanlık Osmanlı Arşivi (Kullanılan belgelerin Fon Kodu, Dosya ve Gömlek Numaraları metin içinde verilmiştir.)

Bayur, Y. H. (1991). Türk inkılâbı tarihi. C. II/Kısım: IV, Ankara: Türk Tarih Kurumu Yay. Bayur, Y. H. (1991). Türk inkılâbı tarihi. C. III/Kısım: III, Ankara: Türk Tarih Kurumu Yay. Bayur, Y. H. (1991). Türk inkılâbı tarihi. C. III/Kısım: IV, Ankara: Türk Tarih Kurumu Yay. Bayur, Y. H. (1991). Türk inkılâbı tarihi. C.II/Kısım IV, Ankara: TTK Yay. Birinci dünya harbinde Türk harbi, c.I, Genelkurmay ATASE Başk. Yay., Ankara, 1991. https://en.wikipedia.org/wiki/Charles_I_of_Austria(9.10.2015). 
https://en.wikipedia.org/wiki/Robert,_Archduke_of_Austria-Este (26.11.2015)

https://tr.wikipedia.org/wiki/I._Karl (21.12.2015)

Karabekir, K. (1995). Birinci cihan harbine nasıl girdik. c.II İstanbul: Emre Yay.

Karal, E. Z. (1996). Osmanlı tarihi, C. IX, Ankara: TTK Yay.

Küçük, C. Mehmed V. Türkiye Diyanet Vakfi İslam ansiklopedisi, 28, 61-62.

Lütfi S. (1972). Osmanlı sarayının son günleri. İstanbul: Hürriyet Yay.

Özçelik, M. (2012). Avusturya İmparatoru ve Macaristan Kralı'nın 1918 İstanbul ziyaretinin Türk basınına yansımaları. Süleyman Demirel Üniversitesi Fen Edebiyat Fakültesi Sosyal Bilimler Dergisi, 27, 51-63.

Türkgeldi, Â.F. (1987). Görüp işittiklerim. Ankara: TTK Yay.

Y1lmaz, V. (1993).l inci dünya harbinde Türk-Alman ittifakl ve askeri yardımlar. İstanbul: 